\title{
Plant-Microbiome Crosstalk: Dawning from Composition and Assembly of Microbial Community to Improvement of Disease Resilience in Plants
}

\author{
Muhammad Noman ${ }^{1}$, Temoor Ahmed ${ }^{1}$, Usman Ijaz $^{1}$, Muhammad Shahid ${ }^{2}{ }^{\mathbb{D}}$, Azizullah ${ }^{1}$, Dayong Li ${ }^{1}$, \\ Irfan Manzoor ${ }^{3}(\mathbb{D}$ and Fengming Song $1, *$ (i)
}

1 State Key Laboratory of Rice Biology and Ministry of Agriculture Key Laboratory of Molecular Biology of Crop Pathogens and Insects, Institute of Biotechnology, Zhejiang University, Hangzhou 310058, China; nomansiddique834@gmail.com (M.N.); temoorahmed@zju.edu.cn (T.A.); usmanijazahmad1246@gmail.com (U.I.); azizullahkeerio0706@yahoo.com (A.); dyli@zju.edu.cn (D.L.)

2 Department of Bioinformatics and Biotechnology, Government College University, Faisalabad 38000, Pakistan; mshahid@gcuf.edu.pk

3 Department of Biology, Indiana University, Bloomington, IN 47405, USA; imanzoor@iu.edu or rana.arfan84@gmail.com

* Correspondence: fmsong@zju.edu.cn; Tel.: +86-571-8898-2269

check for updates

Citation: Noman, M.; Ahmed, T.; Ijaz, U.; Shahid, M.; Azizullah; Li, D.; Manzoor, I.; Song, F.

Plant-Microbiome Crosstalk:

Dawning from Composition and Assembly of Microbial Community to Improvement of Disease Resilience in Plants. Int. J. Mol. Sci. 2021, 22, 6852. https://doi.org/10.3390/ijms22136852

Academic Editor: Bartolomé Sabater

Received: 4 June 2021

Accepted: 23 June 2021

Published: 25 June 2021

Publisher's Note: MDPI stays neutral with regard to jurisdictional claims in published maps and institutional affiliations.

Copyright: (c) 2021 by the authors. Licensee MDPI, Basel, Switzerland. This article is an open access article distributed under the terms and conditions of the Creative Commons Attribution (CC BY) license (https:// creativecommons.org/licenses/by/ $4.0 /)$.

\begin{abstract}
Plants host diverse but taxonomically structured communities of microorganisms, called microbiome, which colonize various parts of host plants. Plant-associated microbial communities have been shown to confer multiple beneficial advantages to their host plants, such as nutrient acquisition, growth promotion, pathogen resistance, and environmental stress tolerance. Systematic studies have provided new insights into the economically and ecologically important microbial communities as hubs of core microbiota and revealed their beneficial impacts on the host plants. Microbiome engineering, which can improve the functional capabilities of native microbial species under challenging agricultural ambiance, is an emerging biotechnological strategy to improve crop yield and resilience against variety of environmental constraints of both biotic and abiotic nature. This review highlights the importance of indigenous microbial communities in improving plant health under pathogen-induced stress. Moreover, the potential solutions leading towards commercialization of proficient bioformulations for sustainable and improved crop production are also described.
\end{abstract}

Keywords: microbiome engineering; microbiota; pathogens; plant-microbe interactions; rhizosphere; root exudates

\section{Introduction}

Interest in the control of crop diseases has recently increased due to the global requirement for eco-friendly approaches that would replace chemical fertilizers and pesticides in agricultural practices [1,2]. Plants provide the place for the growth of niches and the proliferation of a diverse microbial community, including protists, fungi, bacteria, viruses, and nematodes $[3,4]$. These organisms play important roles in the health and productivity of crops by forming complex co-associations with plants [1]. In particular, plant-associated microbiota and plants form a 'holobiont', and evolutionary selection among microbes and plants contributes to the stability of ecosystem $[5,6]$. Complex plant-microbial associations have deep branching lineages and comprise of diverse phyla at lower phylogenetic resolutions. Recently developed culture-independent high-throughput sequencing has accelerated the identification of microbial communities inhabiting the surrounding spaces, as well as inside tissues and surfaces of plants, and demonstrated the existence of microbial lineage subsets, termed as 'core microbiota', which reproducibly make contacts with host plants across a wide range of environmental conditions [7,8]. Among the plant microbiome, fungi and bacteria, which play significant roles in the proper functioning 
and health of plants $[9,10]$, are dominant microbes in contrast to the other members of community, i.e., archaea, nematodes, algae, and protists. The metagenome/genome-wide association studies (M/GWAS) have enlightened our understanding regarding the roles of individual taxa in modulating plant physiology, colonization and fitness [8], whereby, multi-omic approaches have enabled us to predict and characterize the genes that facilitate the microbes to interact with the plant-associated microbiomes [11]. Based on the current knowledge of plant-microbiome interactions, there is an evolving paradigm that considers plant-microbiome associations/interactions as means to develop novel plant genotypes under continuously changing ambiance $[12,13]$. This review summarizes the recent advances on plant-microbiome interactions at the community level, along with the roles of composition and assembly of a microbial community to improve the disease resilience in plants. Current knowledge gaps and future research directions are also discussed.

\section{Structural Dynamics of Microbiome in Plant Life}

The plant-associated microbiome assembly comprises of a series of successional steps determined by microbe-microbe and plant-microbe interplays (Figure 1). Plant-microbiota generally transmit via either horizontal pathway (i.e., obtained from the vicinal environment) or vertically (i.e., gained directly from the parent) [14]. Although the detailed information on horizontal and vertical modes of transmission remains elusive, their roles in shaping the final diversity of seed microbiota are well-established. Once seeds germinate, microbe assembly is stimulated by horizontal transmission mode, where seed-borne microorganisms mostly get fixed with roots and rhizosphere [15].

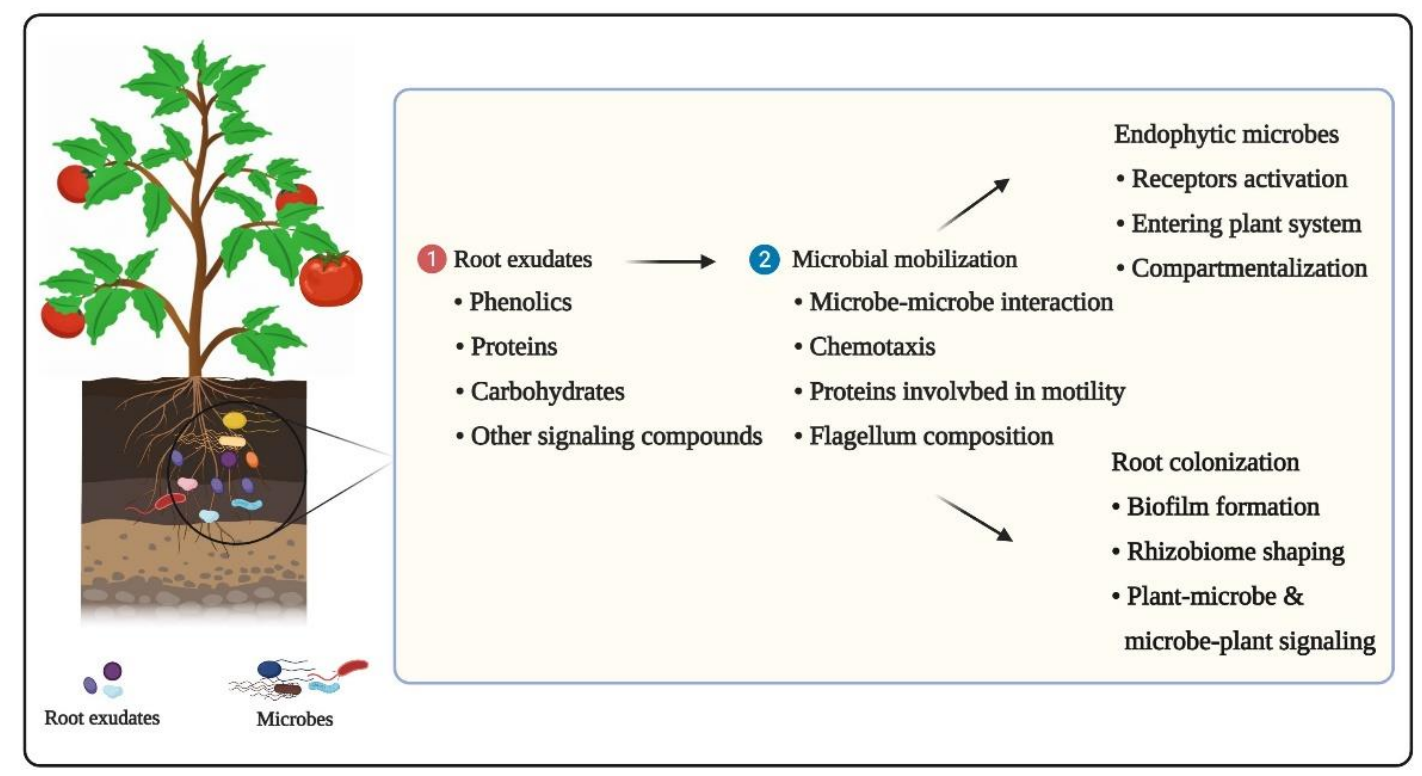

Figure 1. Various steps that occur during the assembly of the plant microbiome are depicted schematically. Firstly, plants release signaling molecules (i.e., phenolics, proteins, etc.) in the form of rhizodeposits to attract microbial community (step 1). Secondly, microbes respond to plant oriented signaling molecules by initiating mobilization and colonizing various plant parts as epiphytes and endophytes (step 2). The final diversity of the plant microbiome is shaped by a series of stages involving intricate signaling between plants and microorganisms.

The microbiome associated with plant roots is dynamically assembled and recruited during life cycle of the host plants. Temporal alterations in structural composition of rhizobiome are constant across different geographic regions around the globe [16]. The microbiome composition is highly dynamic during early vegetative growth stage and sustains in later vegetative stage $[16,17]$. However, some members of microbial taxa belong to the core microbiota, and constantly maintain in relatively high abundances during the developmental phase of the host plants [16-19]. These core microbiota possess several 
beneficial traits, such as endurance of stress, beneficial effects on the host growth, efficient colonization, and to protect host plants from harsh environmental constraints [15,20]. Host plants, on the other hand, can transfer the abovementioned core microbiota-induced beneficial traits to their offspring, revealing the significance of linkage between plantassociated microbiome and host plants [21].

Plants harbor diverse microbial communities, some of which enter the plant tissues, called endophytes, while others stay on the outer surface of plant tissues, known as epiphytes [22,23]. Early studies mainly focused on the structural and functional characterization of rhizobiome, and discovered that plant-soil crosstalk plays a key role in shaping the rhizosphere microbiota [24]. For example, defects in phosphate starvation response (PSR) pathway in Arabidopsis plants negatively regulated the diversity of beneficial microbiota and ultimately favored the colonization of phytopathogens [25]. Plant leaves also offer habitats to complex and diverse microbial communities [26,27]. Most endophytes spread systematically through the xylem system to other compartments of plants such as the leaves, fruits, and stem; however, distinct endophyte communities are present on aboveground plant tissues depending on the plant source allocation [22]. Phyllosphere bacteria initially start their lives in a soil environment, and eventually enter into plant leaves as endophytes, a process driven mainly by environmental and plant factors [28-30]. Features of plant cell walls play key roles in shaping almost $40 \%$ of the bacterial population diversity in the roots of Arabidopsis plants [31]. Host genotype, age, and environment conditions have cumulative impacts on the diversity of rhizospheric and phyllospheric bacterial communities in Boechera stricta, suggesting the importance of genotype-environment interactions in determining the structural assembly of plant microbiomes under natural conditions [32].

Various microbial groups, belonging to different genus and species, inhabit the phyllosphere and endosphere of host plants. For instance, Pseudomonas, Sphingomonas, Frigoribacterium, Pantoea, Acinetobacter, Enterobacter, Methylobacterium, Bacillus, and Curtobacterium are predominant genera of carposphere or phyllosphere microbiota in grapevine [29,33], while Methylobacteria and Sphingomonads are predominant taxa of leaf microbiomes in maize [30]. Similarly, Enterobacteriaceae and Pseudomonas were identified as dominant epiphytic bacteria existing on the flower of apple [34], and Pseudomonas is the most abundant genus found in the leaves of tobacco, apple, pumpkin, grapefruit, and almond [35].

Plant endophytes mainly originate from seed, air, and soil, followed by habituation inside the plant tissues, where they spend rest of their lives. Various factors including environment factors, farm management, plant genotype, and soil features shape the community composition of plant endophytes [26,36]. Plants compartmentalize specific microbial communities as endophytes and establish a strong association as well as a signaling nexus with endophytes [37]. For example, invasion of Xanthomonas oryzae pv. oryzae (Xoo), the causal agent of rice bacterial blight, negatively regulated the endophytic microbial diversity of rice plants by reducing alpha-diversity of the fungal communities, Xoo infection helped rice plants to acquire disease combating beneficial microbes that subsequently elicited the disease-suppressive mechanisms in the plants [38]. However, the composition, interactions, and functions of endophytic bacterial communities in protecting plants from pathogen attack under adverse environmental conditions remain unclear.

\section{Plant-Microbe Interplays: Recruiting Microbial Communities for Microbiome Assembly}

Diverse microbial communities colonize plant surfaces and tissues, where beneficial microbial groups provide plants with a wide array of life supporting functions, such as resilience to biotic and abiotic stresses, growth promotion, and nutrient acquisition [39,40]. Managing microbial colonization process would help to modulate the abovementioned functions, but in-depth understanding regarding how plant genotypes regulate colonization of particular microbial group will be helpful to further strengthen beneficial microbiotalinked traits. The microbiome assembly depends on both plant-microbe interactions and microbe-microbe interactions (Figure 2). 


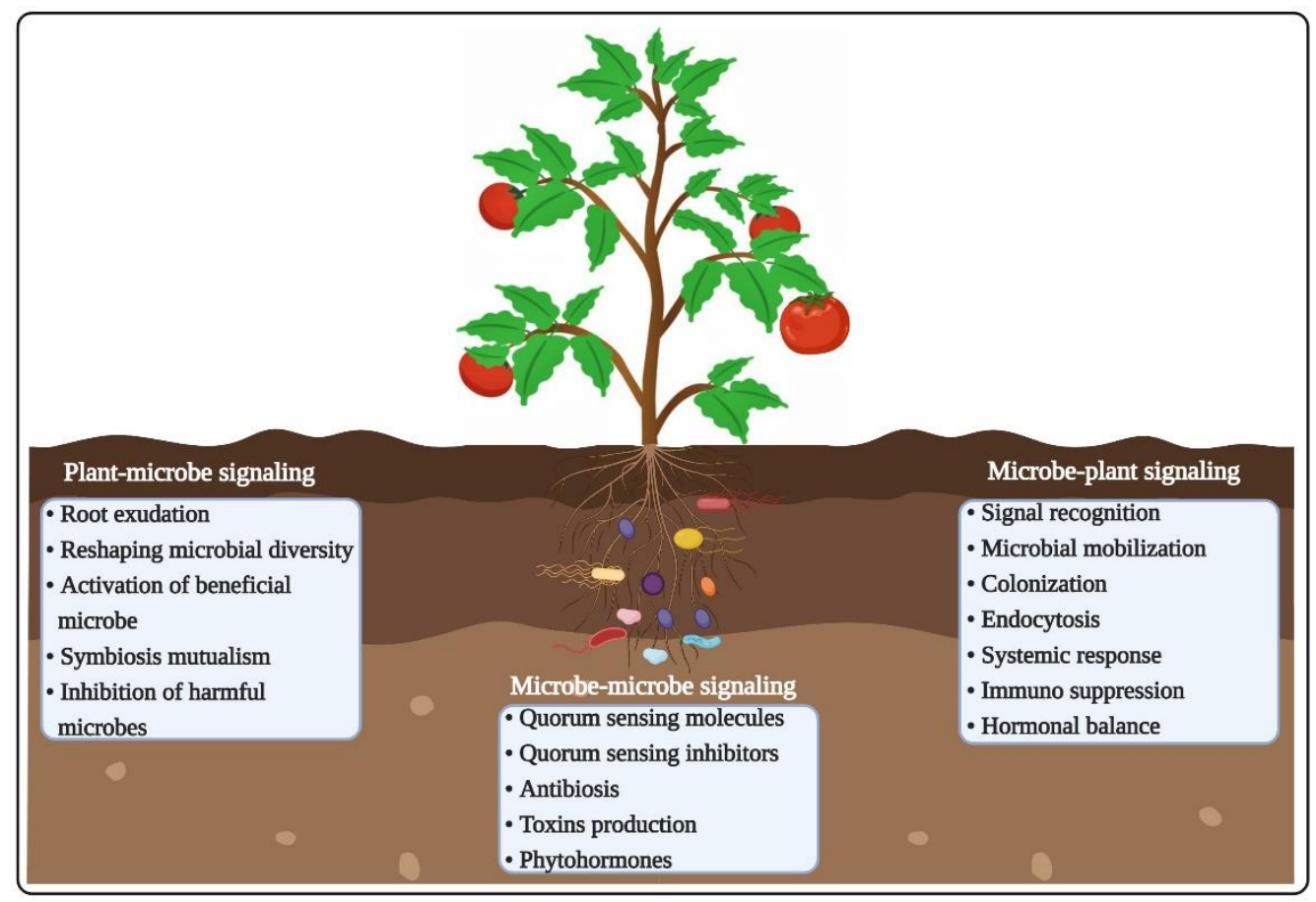

Figure 2. Schematic visualization of various interactions occurring in the plant holobiont. Numerous complex signaling pathways are involved in plant-microbiome crosstalk, including plant-microbe, microbe-microbe, and microbe-plant communications. The ultimate fate of plant-microbiome interactions depends on the chemistry of the rhizosphere, and the diversity and the composition of microbial communities.

\subsection{Root Exudates and Chemotaxis}

Microbes employ chemotaxis to detect and respond to plant-derived signals (i.e., sugars or organic acids), exuded from plant roots, to initiate microbial colonization step. Following the signal perception, microbes mobilize towards plants and become attached to the surface of roots to form biofilm [41]. Genes responsible for motility, chemotaxis, biofilm formation, flagella assembly, two-component regulatory system, and secretions are abundantly present in microbial communities of phyllosphere and rhizosphere, in contrast to the bulk soil [42-44]. Large numbers of substrate transporters present in the members of phyla Firmicutes and Proteobacteria facilitate the habituation of microbial populations in the nutrient rich environment of plants $[4,18,29]$. Similarly, motility genes were also identified in bacterial strains isolated from Arabidopsis thaliana roots [45].

In plants, the compounds that stimulate chemotaxis in microbes are present on the root surface or in root exudates [46-48]. Detailed characterization of root exudates is challenging, owing to the variation in their composition with plant developmental stages, plant varieties, and environmental conditions [49]. However, several compounds have been identified in certain plant species; some are common, while others are unique [41]. Usually, polysaccharides are secreted by root tips and abundantly present in root caps and mucilage [50]. However, elongation zones and meristem contain oxidized compounds such as amino acids, sugars, and organic acids [51,52].

The ability to sense organic compounds widely exists in plant-beneficial bacteria including Azospirillum brasilense, Sinorhizobium meliloti, Rhizobium leguminosarum, and various Pseudomonas species, and specific receptors for different organic compounds have been identified in plant-beneficial bacteria [53]. R. leguminosarum, A. brasilense, and S. meliloti utilize organic acids as catabolite repressors [54]. Organic acids are the key metabolic regulators that help microbial species to adapt to rhizospheric environment, elucidating the widespread distribution of organic acid-mediated chemotaxis in plant-associated bacteria [55]. Microbes sense the molecules of interest present in root exudates indirectly, by periplasmic binding proteins and a phosphotransferase system followed by the attachment 
to corresponding receptors. For instance, a galactose binding periplasmic protein (i.e., $\mathrm{ChvE}$ ) is involved in chemotaxis of $A$. brasilense, although the interacting chemoreceptors are still unknown [56]. R. leguminosarum and S. meliloti perform nitrogen fixation only during symbiotic association, and rely on other nitrogen sources (i.e., amino acids) under free-living conditions [54]. In addition, chemotaxis towards flavonoids, host-specific phenolic compounds exuded in low amount from plant roots, regulates the expression of nodulation genes in bacteria [57]. Some of the rhizodeposits secreted by different plants, together with microbial responses and effects, are presented in Table 1.

Table 1. Summary of some root exudates involved in plant-microbe crosstalk with subsequent impact on plant microbe symbiosis.

\begin{tabular}{|c|c|c|c|c|c|}
\hline Root Exudates & Microbial Receptors ${ }^{1}$ & Microbes & Plant Species & Effects & References \\
\hline Alanine & $\begin{array}{c}\mathrm{CtaA}, \mathrm{CtaB}, \mathrm{CtaC} \\
\text { and } \mathrm{CtaD}\end{array}$ & $\begin{array}{c}\text { Pseudomonas protegens } \\
\text { CHA0 }\end{array}$ & Tobacco & Suppresses root disease & [58] \\
\hline Arginine & McpA & Azospirillum caulinodans & Sesbania rostrata & $\begin{array}{l}\text { Regulates root colonization and } \\
\text { flagella synthesis }\end{array}$ & [59] \\
\hline Chitinase & McpU & Pseudomonas sp. RP2 & Arachis hypogaea & Increases immunity & {$[55]$} \\
\hline Choline & $\operatorname{McpX}$ & Sinorhizobium meliloti & Alfalfa & $\begin{array}{l}\text { Facilitates nitrogen-fixation in } \\
\text { root nodules }\end{array}$ & {$[60]$} \\
\hline Citric acid & McpU & Sinorhizobium meliloti & Alfalfa & Regulates root colonization & {$[61]$} \\
\hline Citric acid & McpU & Bacillus subtilis & Arabidopsis thaliana & $\begin{array}{c}\text { Enhances root binding of } \\
\text { Bacillus subtilis }\end{array}$ & {$[62]$} \\
\hline Ethylene & ETR1 & Azospirillum brasilense & Wheat & Modulates plant morphology & {$[63]$} \\
\hline Malic acid & McpU & Bacillus subtilis & Rice & $\begin{array}{l}\text { Improves nutrient assimilation } \\
\text { and pH regulation }\end{array}$ & {$[64]$} \\
\hline Malic acid & McpA & Pseudomonas fluorescens & Tomato & $\begin{array}{c}\text { Improves plant growth and } \\
\text { nutrient acquisition }\end{array}$ & {$[65]$} \\
\hline $\begin{array}{l}\text { Methyl- } \\
\text { glucoside }\end{array}$ & McpA & Bacillus amyloliquefaciens & Cucumber & $\begin{array}{l}\text { Modulates chemotaxis mobility } \\
\text { and enhances immunity }\end{array}$ & {$[48]$} \\
\hline Nicotine & McpU & Pseudomonas aeruginosa & Tobacco & $\begin{array}{l}\text { Increases biocontrol efficiency } \\
\text { against bacterial wilt }\end{array}$ & {$[66]$} \\
\hline Oxalic acid & TlpA1 & Azospirillum caulinodan & Sesbania rostrata & Increases plant growth & {$[67]$} \\
\hline Proline & IcpB & Pseudomonas aeruginosa & Cucumber & $\begin{array}{l}\text { Shows antifungal activity } \\
\text { against Fusarium oxysporum }\end{array}$ & {$[68]$} \\
\hline Proline & McpB & Bacillus velezensis & Maize & $\begin{array}{l}\text { Regulates swarming motility } \\
\text { and biofilm formation }\end{array}$ & [69] \\
\hline Proline & McpU & Sinorhizobium meliloti & Alfalfa & $\begin{array}{l}\text { Directs flagellar motor rotation } \\
\text { and root colonization }\end{array}$ & {$[54]$} \\
\hline Succinic acid & TlpA1 & Azospirillum brasilense & Wheat & $\begin{array}{l}\text { Increases plant growth, root } \\
\text { volume, and crop yield }\end{array}$ & {$[41]$} \\
\hline Succinic acid & TlpA1 & Bacillus velezensis & $\begin{array}{l}\text { Brachypodium } \\
\text { distachyon }\end{array}$ & Regulates biofilm formation & {$[51]$} \\
\hline Tryptophan & IcpB & Azorhizobium caulinodans & Sesbania rostrata & $\begin{array}{l}\text { Modulates nodulation and } \\
\text { nitrogen fixation }\end{array}$ & {$[70]$} \\
\hline Tryptophan & IcpB & Bacillus cereus & Tomato & $\begin{array}{l}\text { Reduces the damage of } \\
\text { Medoidogyne incognita }\end{array}$ & {$[71]$} \\
\hline
\end{tabular}

${ }^{1} \mathrm{CtaA}, \mathrm{CtaB}, \mathrm{CtaC}$, and $\mathrm{CtaD}$ are the chemoreceptors for amino acids; $\mathrm{McpA}, \mathrm{McpU}$, and McpX are chemotaxis sensory proteins that detect chemotactic ligands; ETR1 is a membrane-localized histidine kinase chemoattractant receptor for ethylene; TlpA1 is a transmembrane chemoreceptor that responds to various organic acids, glycerol, and proline; and IcpB is a heme-binding soluble chemotaxis sensory protein that senses organic acids.

Root colonization is generally triggered by Rhizobiales (part of the core microbiome) equipped with symbiosis-related genes [72]. In the interface of plant rhizospheres, polyamines, i.e., putrescine and arginine, act as signaling molecules and stimulate the lifestyle switch in a microbial group to promote attachment and biofilm formation [73,74]. After successful colonization within host plants, diverse processes, such as nutrient 
deficiency-mediated root inhibition and/or activation of signaling pathways, take place, which alter the root architecture of the host plants, resulting in differential niche colonization patterns between many microbial groups [75].

\subsection{Microbe-Microbe Interactions}

It is not surprising that various active genes of soil microbiota play significant roles in competition or cooperation with other microbes. Microbes can synthesize different products, which affect the microbe-microbe interactions. Distinct and diverse gene clusters for biosynthesis of natural products have been identified in plant-associated bacteria [76]. The genomes of plant-associated bacteria harbor biosynthetic genes for intraspecific or interspecific bacteria-killing substances (such as antibiotics and toxins) to control the abundance, diversity, and distribution of other microbial groups in host plants [55]. However, how these compounds are synthesized, and how they regulate the microbe-microbe interplays, along with their underlying biochemical mechanisms, remains to be explored.

Specific functional traits correlated with pathogen suppression, e.g., biosynthetic genes for antifungal compounds and protein secretion, are rich in bacterial disease combating rhizobiomes of tomato and soybean $[77,78]$. Pathogens induce the activation of various unknown biosynthetic gene clusters (BGCs), encoding polyketide synthases (PKSs), chitinases, and non-ribosomal peptide synthetases (NRPSs), which subsequently trigger the disease suppression activity in the endophytic root microbiome [79]. More than one thousand BGCs belonging to diverse biosynthetic classes of terpene system, post-translationally modified and ribosomally synthesized peptides, trans-AT PKSs, and NRPSs have been identified in phyllospheric bacteria of Arabidopsis plants [80]. These BCGs are involved in driving the complex interactions occurring within a microbial niche [81]. In addition to the abundance of antibiotic production, antibiotic resistance genes are also widely distributed within the microbiome [6], implying an intense competition between different microbial groups that controls the structure of microbial community.

Quorum sensing (QS) is a well-established mechanism by which bacteria communicate with one another by sensing and producing signaling molecules, e.g., homoserine lactone (HSL) [82]. Different bacterial taxa have the ability to generate the same type of signaling molecules, which enable either interference or cooperation with the neighboring microbes belonging to other taxa [83]. QS facilitated the movement of finger millet endophyte M6 (Enterobacter sp.) towards the root invading microbe Fusarium graminearum, and resulted in the development of biofilm on root hair to trap and prevent the entry of endophytic pathogen [84]. Terpene and HSL biosynthetic genes are enriched in microbial communities [82]. Terpenoids play roles in diverse ecological and biological functions, including chemical defense against pathogens and herbivores $[85,86]$. Bacterial terpenes are also involved in interkingdom signaling, as these compounds function as elicitors of profound responses in plants [87]. Microbial colonization on the 'local side' stimulates the microbial colonization on the 'systemic side' by modulating root exudation of metabolites via long-distance communication with different parts of rhizospheric system [88]. For instance, locally inoculated bacterial strains belonging to genera Bacillus and Pseudomonas trigger the production of bacteria-specific metabolites in the root exudates, which, in turn, induce the colonization of selective bacterial groups on the systemic side [89]. QS is an intercellular communication system, in which particular signal molecules including AHLs mediate bacterial gene expression and bacterial cell concentration [90]. In fact, QS system controls the production of a variety of phenotypes, many of which have been linked to pathogenesis in a variety of economically significant bacterial pathogens, such as Pectobacterium carotovorum, Pseudomonas syringae, Dickeya solani, Ralstonia solanacearum, Erwinia amylovora, and Agrobacterium tumefaciens [91]. In agriculture, interference or interrupting QS is thus an intriguing technique for preventing pathogen infections [92]. Quorum quenching (QQ), involving the enzymatic destruction of AHL signal molecules, is one of the most well-known QS-interrupting techniques [93]. For example, the QQ activity of Pseudomonas segetis strain P6 reduced soft rot symptoms on potato and carrot caused by $D$. 
solani, P. carotovorum, and Pectobacterium atrosepticum [91]. Moreover, plants are also able to disrupt the QS system by producing QS inhibitors, which either degrade QS signals or compete for signal receptors. For example, extracts from Medicago truncatula, cinnamon, grapefruit, and other edible plants and fruits showed QS inhibition activity against plant pathogens [94]. Bioactive molecules produced naturally by marine organisms and fungi and chemically synthesized compounds and antibodies have been reported to act as QS inhibitors. An interesting feature of QS inhibitors is that they operate at lower than minimum inhibitory concentration. Thus, pathogens do not perceive threats to their survival, and continue to grow without causing disease $[95,96]$.

Microbial populations that can successfully colonize may not only rely on colonization signals from host plants, but also possess genetic machinery to compete with other members of the microbiome [97]. Multiple type VI secretion system (T6SS) genes, which are involved in the production of toxic proteins to kill competitor cells, have been identified in the microbial communities of wheat, cucumber [98], barley [99], and citrus [6]. Hyde1, a new family of T6SS effectors identified in pathogenic Acidovorax spp., was found to control the growth and proliferation of phyllospheric bacteria, revealing its involvement in interbacterial competition for plant colonization [44]. Therefore, an array of factors, such as fitness for competition, survival rate, ability to respond to plant-oriented signals and environmental conditions, may collectively affect the colonization process of microbial groups. However, integrated studies of modelling and synergistic interactions occurring in the plant holobiont are required to completely understand the molecular basis of complex web of microbial associations.

Recent studies have provided new insights into the role of eco-evolutionary processes, such as microbial shift between niches, selection of the fittest microbial group, ecological drift, and genetic diversification, in the microbial community assembly process [39]. Random habituation and past events have substantial impacts on the structure of microbial community in plant microbiomes. Initially, random processes trigger the colonization of rhizospheric and phyllospheric microbial communities $[17,100]$. Despite the robustness of primary microbial communities, plants can accommodate new species without any major change in existing microbiome structure. Deciphering the driving machinery behind the assembly, dynamics, occurrence, and sensitivity to biotic/abiotic factors is necessary to highlight the role of microbiomes in plant physiological responses to challenging environmental conditions.

\subsection{Plant-Pathogen Interactions}

Plant-pathogen interactions are mediated by interplays of multifaceted processes, which are facilitated by the pathogen- and plant-oriented molecules [101,102]. Molecules secreted by pathogens are the main factors, which control their successful penetration, colonization, and pathogenicity inside the host plants [103]. For instance, Zymoseptoria tritici, a devastating wheat pathogen, favored its infection process by suppressing immune responses of wheat plants via altering benzoxazinoids and phenylpropanoids biosynthetic pathways [104]. By contrast, plant-derived molecules are responsible for the pathogen recognition to provoke an array of defense responses within plants. The interactions between the pathogens and the plants are normally initiated in apoplast, followed by the recognition of microbial elicitors by receptors in plants [105]. These elicitors, termed as pathogen-associated molecular patterns (PAMPs), are generally recognized by membrane localized pattern recognition receptors (PRRs) in plants [102,106,107]. Bacterial flagellin, peptide surrogates, elongation factor (EF), chitin, elf18, and flg22 are common PAMPs, which are usually recognized by PRRs, i.e., chitin elicitor receptor kinase1 (CERK1), EF-Tu receptor (EFR), and flagellin-sensitive2 (FLS2), respectively.

Recognition of microbe-derived PAMPs by plant PRRs triggers the first line of defense in host plants, termed as PAMP-triggered immunity (PTI). To overcome PTI, pathogens evolutionarily develop and deliver a large number of effector proteins into their host cells to inhibit or scavenge the PTI components $[108,109]$. Among these, avirulence (Avr) 
proteins, such as transcription activation-like effectors (TALEs) of Xanthomonas oryzae and S1p1 of Magnaporthe oryzae, are the common examples of microbial effectors that chock the defense responses of host plants [102]. As consequence, however, plants encode various disease resistance $(R)$ proteins to recognize pathogen-associated Avr proteins [108]. Molecular interactions between host-derived $R$ and pathogen-oriented Avr proteins activate the second line of defense, known as effector-triggered immunity (ETI). ETI is relatively faster and stronger than PTI, and usually induces localized necrosis of both pathogen and plant cells in the infected area $[110,111]$. PTI and ETI together constitute the innate immunity system in plants, which enable plants to recognize and resist/combat against invading pathogens.

The fate of plant-pathogen interactions is decided by various environmental factors including cultivation conditions, genetic basis of plants and pathogens, variations in host physiological responses under biotic/abiotic climate changes, and the structure of the host-associated microbiome [17]. For example, the bacterial pathogen, Pseudomonas fuscovaginae, was responsible for disease incidence in highland rice plants, while the fungal pathogen, Sarocladium oryzae, was found to cause infection in rice plants grown at low altitudes, especially during wet season [112]. The plant microbiome, especially rhizobiome, acts as a protective shield and obstructs plant-pathogen interplays with subsequent beneficial impacts on plant health [113]. Plant-associated microbial communities hinder the pathogen-oriented activities via competing for resources, locking key nutrients (i.e., iron) and producing pathogen-killing metabolites (such as antibiotics and toxins) that ultimately eradicate the pathogens $[114,115]$. Furthermore, plant-beneficial microbiota also interrupt the communications between pathogens and their corresponding hosts indirectly, by inducing systemic resistance in plants (described in later sections) [116]. Recently, the indigenous plant-associated microbial communities have attracted the attentions of the scientific community, owing to their functional benefits on plant health under challenging climatic conditions $[117,118]$.

\section{Functions of Microbiome in Plant Health}

Generally, each microcosm member possesses several valuable traits that help to regulate the physiological processes in the host plants under diverse environmental conditions. Specific traits displayed by an individual microbial group in the microbiome is of significant importance regarding plant health, and is influenced by variety of factors including microbial diversity, environmental factors, and host plant species $[119,120]$. The direct health-related benefits provided by the microorganisms to their host plants include nutrient acquisition, mitigation of environmental stresses, and protection from pathogens [59]. Plant microbiomes have long been studied for their role in protecting their hosts from phytopathogens, and the term "biocontrol" refers to the processes that eliminate disease-causing organisms [121]. Usually, beneficial microbes protect plants from pathogen attacks either directly (by interacting with pathogens) or indirectly (by activating the innate immune responses of the host plants).

\subsection{Roles in Direct Suppression of Plant Pathogens}

The plant-microbiota members include neutral, pathogenic, and beneficial organisms. During their lifespan, plants not only establish beneficial associations with microbial communities, but also need to cope with the infections caused by diverse pathogenic microorganisms. Soil-borne pathogens cause adverse effects on hundreds of plant species, including economically important crops, leading to significant economic losses by reducing quality and yield [122-124]. The most important soil-borne fungal pathogens are Rhizoctonia solani [125], Fusarium oxysporum [126], Verticillium spp. [127], and Fusarium solani [4]. These soil-borne pathogens can survive in soil for long periods of time by forming resting structures (such as chlamydospores, melanized mycelia, oospores, cysts, and sclerotia) until they receive life signals from their corresponding host plants [59]. For example, free amino acids, phenolic compounds, and sugars in root exudates of watermelon and tomato 
significantly enhanced the sporulation and spore germination of $F$. oxysporum $[128,129]$. The infection of soil-borne pathogens usually causes root development inhibition, root rot, stunted growth, stem or collar rot, wilting, and seedling damping-off of plants [130,131], and some of the soil-borne pathogens infect a wide range of host plants rendering traditional control measures ineffective [132]. A few groups of soil-inhabiting bacteria have been known to negatively regulate the plant health. For instance, A. tumefaciens, the causal agent of crown gall disease [133], and R. solanacearum, causing bacterial wilt, are widely studied plant-damaging soil-borne bacteria [134].

Pathogens must interact with the complex microbial community of rhizosphere to develop an intense pathogenic impact on plants [135]. Pathogens negatively affect the plant health by interacting with beneficial microbiota, i.e., competing for nutrients and space, and the production of antimicrobial compounds [136]. Furthermore, pathogens also promote the colonization of other plant-harmful microbes by delivering effector proteins that cease the activities of beneficial microbes in rhizosphere community [136]. Plants and their associated microbiota are evolving simultaneously for millions of years, and this co-association of microbes and plants provides several benefits to plants including nutrient acquisition, fight against abiotic stresses, and disease suppression [111]. Hostlinked communities of beneficial microbes are involved in disease suppression and nutrient mobilization in plants $[137,138]$. For example, Pseudomonas spp. can reduce the growth of plant pathogens through competition and antibiosis; however, the overall disease suppression in soil is affected by multiple factors, i.e., genetic background of both hosts and pathogens, population dynamics of pathogens, diversity and composition of plant microbiota, as well as biotic and abiotic conditions [42,139]. Although the disease suppression ability is associated with synergistic efforts of microbes rather than individual specific efforts [140,141], complete understanding of underlying interactions between potential antagonists and disease-causing phytopathogens requires further investigation. Some simple mechanisms, i.e., production of antimicrobial metabolites and volatiles in antagonistic bacteria, have been reported to be responsible for improving the efficacies of the diseasesuppressive soils [142,143]. Among all mechanisms of disease suppressive soils, antibiosis (i.e., production of antimicrobial metabolites by an organism to suppress the growth and proliferation of another organism) is the most widely studied [144]. Antibiotics such as 2,4-diacetylphloroglucinol (DAPG) and phenazines (PHZ) have been well-studied, owing to their potential roles in plant disease suppression $[144,145]$. Several Pseudomonas species produced DAPG and PHZ in soils, which suppressed Fusarium wilt of flax or wheat [146]. Moreover, DAPG and pyrrolnitrin suppressed the growth of $R$. solani [147], while PHZ and pyoluteorin were widely distributed in soils and are involved in the suppression of Thielaviopsis basicola [148]. A rice seed endophyte, Sphingomonas melonis, promoted the rice panicle rot disease suppression in rice seedlings by producing anthranilic acid against Burkholderia plantarii [149]. Similarly, microbes with inherent potential of volatile organic compound production have been proposed as key components of disease suppressive soils [144]. Earlier studies highlighted the potential role of ammonia and hydrogen cyanide in suppressing the growth of phytopathogens $[144,150,151]$. Inhibition of the proliferation of pathogens in soil can be mediated by competition between plant-beneficial and -harmful microbes for survival, nutrient acquisition, and colonization [152,153].

If a pathogen successfully surpasses the rhizobiome, the so-called first line of defense against invading pathogens, and enters the plant, endophytes come into action to provide plants with an extra layer of protection. Upon pathogen entry, endophytes start recruiting microbial communities, which initiate their genetic machineries to produce defensive enzymes and metabolites against pathogens [79]. Fusarium wilt disease in various crops (e.g., tomato, lettuce, and cucumber) was suppressed when these crop plants were grown in disease suppressive soils enriched in bacterial phyla named Acinetobacteria and Firmicutes [12]. General or specific disease suppression can be achieved via modulating the composition of microbial communities by implementing different management practices, such as crop rotation and compost addition [154]. 
Genomic studies have added more knowledge about the presence of specific gene clusters that are involved in pathogen inhibitory activities. These specific gene clusters also lead towards the identification of antibiotics [80]. Plant-associated microbes are good sources of potential antagonists which can resist phytopathogens. These microbiomes interact directly with pathogens and inhibit their growth [155]. Additionally, niche overlap with microbes for resource competition is also considered a major factor in stimulating biocontrol activity [118].

\subsection{Roles in Activation of Plant Immune Response}

Emerging evidence has indicated that plant-associated microbiomes are engaged with plant health [156] and the beneficial features of plant-associated microbes can boost the immune responses in plants against biotic/abiotic environmental constraints [118,157]. Essentially, microbiomes help their host plants to gain resistance against pathogens via modulation of plant defense mechanisms [158,159]. The microbe-triggered immune response makes plants resilient against pathogen attack with a substantial boost in the disease combating efficiency $[160,161]$. Microbiomes can reinforce the defensive capabilities of plants by interrupting the plant-pathogen interactions, which subsequently improve the disease resilience in plants [89]. Bacterial antagonists belonging to Achromobacter, Comamonas, Curtobacterium, Enterobacter, Leclercia, Microbacterium, Pantoea, Sphingobacterium, and Stenotrophomonas genera showed tremendous biocontrol potential against $M$. oryzae and triggered the expression of defense genes, such as OsCEBiP, OsCERK1, OsEDS1, and OsPAD4, in rice seedlings against rice blast disease [162]. Similarly, root-associated Pseudomonas sp. EA105 and Pantoea sp. EA106 induced disease suppression in M. oryzaechallenged rice plants by triggering jasmonate- and ethylene-dependent induced systemic resistance (ISR) responses [163]. Pathogen attacks induce changes in the root exudation pattern of host plants, which can result in the colonization of specific resistance-inducing microbiota. Diverse microbial populations inhabiting the episphere and endosphere are involved in the activation of defense machinery of tomato plants against F. oxysporum attack by inducing cell wall fortification through the modulation of salicylic acid biosynthesis pathway [141,164]. Moreover, the root-associated microbiome induced resistance in strawberry plants against two soil-inhabiting fungal pathogens, Verticillium dahliae and Macrophomina phaseolina, in controlled field trials [165]. Similarly, a field trial revealed a positive correlation between the microbiome-triggered ability of maize plants and the suppression of a disease caused by $R$. solani [166]. Several microorganisms could induce plant immune responses under greenhouse conditions, but the majority failed in field conditions. This inconsistency is mostly linked to the lack of ability of the microorganisms to survive and colonize the rhizosphere under inappropriate environmental conditions that ultimately affects their protective qualities in field circumstances [144]. Overall, environmental conditions and soil health play important roles in the development of such beneficial plant-microbe interactions.

Rhizobacteria conferred ISR is one form of the inducible immunity in plants, and the molecular mechanisms in ISR are conserved in different plant species [167]. Some of the components present on the cell surface of biocontrol bacteria, i.e., flagella or polysaccharide [168], can trigger ISR in plants [169]. The ISR response in plants can also be triggered when they come into direct contact with compounds secreted by beneficial bacteria, e.g., volatile 2,3-butanediol [170], DAPG, and cyclic lipopeptide surfactants [171]. A transcription factor, MYB72, is involved in the regulation of ISR in A. thaliana [172]. Occurrence of ISR indicates that plants might be evolved in such a way that they use associated microbes as signals for the stimulation and maturation of their immune system. Indeed, plants require microbes during the early stages of life to be in contact with soil for their survival [17]. On the other hand, ISR inducing strains regulate the plant-pathogen interactions via regulating the secretion of antimicrobial compounds by roots $[137,173]$. Alterations in the composition of root exudates ultimately manipulate root microbiomes and activate recruitment of plant-beneficial microbial groups in the rhizosphere [174]. 
Microbiome-induced resistance has been reported in different plant species for various diseases, including potato scab, sugar beet Rhizoctonia damping-off, Fusarium wilt, and wheat take-all $[118,175]$. Colonization of potential antagonistic bacteria conferred resistance to tomato plants against bacterial wilt pathogen $R$. solanacearum [77]. These observations indicate the possibility that the plant immune responses can be modulated by facilitating the recruitment of resistance-inducing microbes that ultimately help plants to sustainably combat pathogen attacks. Selective enrichment of microbial groups is responsible for the induction of immune responses in plants against biotic and abiotic stresses, and this induced immunity can be transferred over generations [176]. However, ISR-inducing microbes need to bypass the plant immune system to develop a symbiotic relationship with their host plants. Beneficial microbes employ mechanisms similar to pathogens which suppress activities of plant immune responses $[177,178]$. For example, Rhizophagus intraradices, an ISR-inducing arbuscular mycorrhizal (AM) fungus, suppresses plant immune responses and promotes its root colonization by producing SP7 effector [179]. Likewise, Laccaria bicolor, a symbiotic ectomycorrhizal fungus, successfully colonizes plant tissues by suppressing salicylic acid-mediated immune responses through MiSSP7 effector [180]. Moreover, compromised immune responses have also been reported in A. thaliana after colonization by Trichoderma [181], Bacillus subtilis [182], and Pseudomonas fluorescens WCS417r [183]. In addition to downregulating local immune responses to facilitate colonization, plant-beneficial microbes also produce elicitors/signals to activate systemic immune responses [137]. However, the detailed molecular mechanisms of mutualistic plant-microbe interactions need further investigation. The beneficial services provided by the microbiome to pathogen-challenged plants are presented in Figure 3.

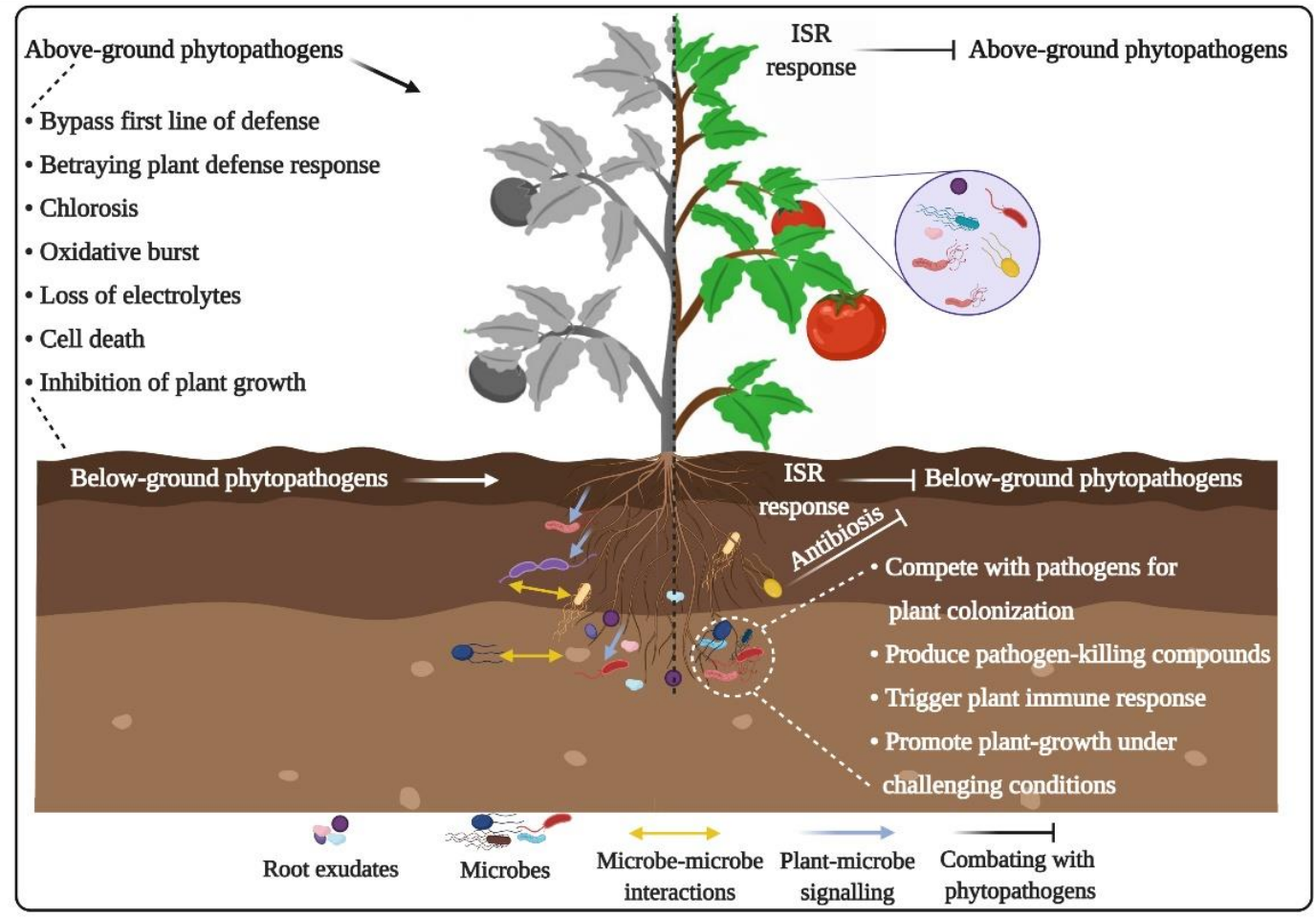

Figure 3. Beneficial impacts of positive plant-microbe interactions on plants. In plants, pathogen-oriented molecular patterns (i.e., PAMPs) or plant-beneficial bacteria activate induced systemic resistance (ISR). Positive interactions between plant and microbiome help plants in combating diseases and other environmental stresses, as well as boosting growth and biomass production. Beneficial plant-microbiota compete with phytopathogens for colonization, resources, and habitat, etc. Overall, beneficial microbes, through numerous mechanisms, including antibiosis, toxin production and nutrient sequestration, directly suppress the proliferation of pathogens and the symptoms of infections in plants. 


\section{Microbiome Engineering: Plausible Functional Benefits on Plant Health}

Plant microbiota is one of the primary factors responsible for the growth and development of plants under diverse environmental conditions [184]. Several emerging microbiome engineering strategies, such as soil conditioning, artificial microbial consortia, and host-dependent microbiome engineering, have been shown to strengthen these features of stress tolerance, disease resistance, and nutrient acquisition in host plants (Figure 4).

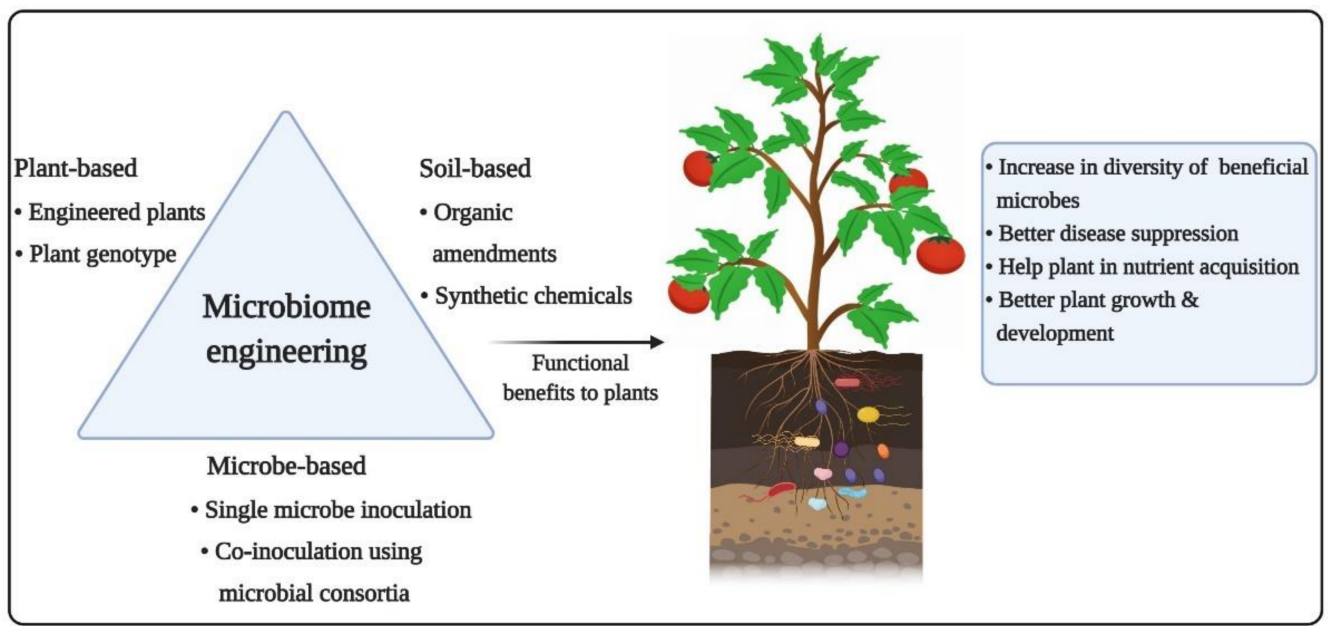

Figure 4. Different microbiome engineering approaches, such as cultivation of microbe-recruiting plant cultivars, inoculation of synthetic microbial communities, and conditioning of soil using suitable amendments, increase the diversity of functionally active and diverse microbial communities, resulting in improved plant health under adverse environmental conditions.

\subsection{Traditional Soil Conditioning Using Organic and Chemical Amendments}

Improvement of soil health is associated with consistent diversity of functional microbiota that will ultimately result in environmentally resilient and higher-yielding crops. Soil organic formulations can be used for supporting the growth and proliferation of functional microbial groups, and include compost, organic residues, organic wastes, biochar, and peat [11]. Biofumigation, as an organic soil conditioning, is a strategy to suppress diseases via soil fungistasis [185]. Amendment of soil with organic conditioners can enrich in positive, functionally more efficient, and interrelated species of microbes compared to supplementation with chemical fertilizers [186]. Functional characterization of positive microbial groups responding to specific organic amendments, and optimization of organic soil amendment applications for particular crop/soil type, will help to better understand the biochemistry of soil health and establish sustainable soil health.

Plant-oriented signaling molecules, such as salicylic acid and various metabolites in root exudates, strongly affect the dynamics and composition of microbiome [156,187], suggesting that plant microbiomes can be artificially modulated using such types of microbe-stimulating chemicals in an efficient and precise manner. For example, phenolic compounds (i.e., coumarins) exuded from plant roots have an assisting role in altering the composition of root-colonizing microbes [188]. Several studies suggested the protective role of coumarins for plants against soil-borne pathogens by facilitating the growth of beneficial rhizobacteria [188,189]. In maize plants, another class of root exudates, called benzoxazinoids, has been shown to protect plants from herbivore insect attacks by favoring the recruitment and colonization of beneficial bacterial and fungal microbial groups in rhizosphere [190]. Further investigations on how different root exudates, such as malic acid, coumarins, benzoxazinoids, and camalexin, can contribute towards microbiome engineering and chemical communications between a particular signaling molecule and microbial group will help to develop host-specific biofertilizers. 


\subsection{Microbiome Engineering Using Artificial Microbial Consortia}

Like synthetic biology, the function and structure of plant microbiomes can be modulated in a more specific manner by using the approach of microbiome engineering encompassing the use of artificial microbial consortia (AMC). This approach enables us to establish AMC equipped with multiple functions relevant to plant growth and development under normal and challenging environments. Such a strategy provides the best alternative to solve numerous drawbacks associated with traditional biofertilizers, such as the inability to compete with microbes under field trials, compromised performance under local environment, and host compatibility issues [191]. The fabrication of an ideal AMC is a systematic approach involving a series of steps including the selection of microbe origin, excavating and culturing the core microbiota, identification of functionally active microbial groups, fine-tuning the microbe-microbe interactions, and the evaluation of consortium efficacy [192].

Numerous microbes establish complex interaction networks with other microbes in the rhizosphere, and have become a key part of the functional consortia. For example, plant growth promoting rhizobacteria (PGPR) and AM fungi can complement one another with respect to ecosystem functioning and nutrient availability [193]. Similarly, key microbial strains can also be artificially inoculated into soils to alter the structure of microbial communities [194]. The role of AMC in conferring stress tolerance to plants is well documented [172,195]. For example, co-inoculation of AM fungus Claroideoglomus claroideum and plant-beneficial bacterium Pseudomonas libanensis into sunflower rhizospheres promoted plant growth by stimulating the growth of plant-beneficial microbiota under salinity or metal stress [196]. Similarly, treating chili plant roots with a bacterial consortium including Acinetobacter sp., Bacillus velezensis, and Bacillus amyloliquefaciens promoted the plant growth and disease suppressive ability against soil-borne Phytophthora capsica [2]. In addition, Agrobacterium sp. modulated the bacterial community shift in rhizospheric region by promoting the growth of various PGPRs, e.g., Brevibacterium spp. and Actinomycetes spp. [197]. The Agrobacterium-induced microbial community shift exerted beneficial effects to bean plants by increasing overall plant biomass, antioxidants, flavonoids, potassium content, and root nodules $[197,198]$. Moreover, co-inoculating the rhizospheres of tomato with Stenotrophomonas maltophilia and Pseudomonas stutzeri boosted the plant growth and stimulated the production of diffusible compounds (i.e., dimethyl disulphide), which are active against the foliar pathogen Botrytis cinerea [199]. Two synthetic microbial communities, comprising bacterial strains with 1-aminocyclopropane-1-carboxylic acid deaminase activity, were recently constructed, and these synthetic microbial consortia showed antimicrobial potential against $F$. oxysporum f. sp. Lycopersici and promoted the growth of tomato plants [200]. Similarly, co-inoculation of pea plants with Pseudomonas aeruginosa, Trichoderma harzianum, and B. subtilis enhanced the defense response against Sclerotinia sclerotiorum through regulating antioxidant enzymes activities and accumulation of phenolic compounds upon pathogen attacks [201]. Application of co-cultures of Azospirillum sp. and $P$. fluorescens was also effective in controlling the root rot disease of cotton caused by Rhizoctonia bataticola [202]. Further studies unraveling the complex nexus between plant genotypes and microbial species/strains are necessary to enlighten our understanding regarding the mechanistic effect of antagonists on disease suppression. Sustainability of synthetic microbial consortia needs to be considered under field conditions, and may be achieved through continuous applications of AMC at regular intervals to stabilize microbial consortia over the generations of host plants.

\subsection{Host Genotype-Dependent Microbiome Engineering}

Beneficial microbes are mainly present in rhizospheres, and plant roots act as a gatekeeper to allow only beneficial microbes to enter plants as endophytes $[193,199,203]$. Plants also expel bacterial species into the rhizosphere, but the underlying mechanisms by which microbes (beneficial or pathogenic) exit and enter the holobiont of plants remain unknown [204,205]. Moreover, plant roots have the ability to consume associated-microbes 
directly as a source of nitrogen [206], indicating that microbial biomass in rhizosphere play an essential role in plant development in an unspecific manner. However, further investigation is required to understand whether plants favor specific microbes for consumption. Plant genetic machinery plays key roles in shaping and functioning of microcosms [11]. For example, Pseudomonas simiae WCS417r boosted the biomass production in Arabidopsis plants of some accessions [207]. The phyllospheric microbial diversity altered in mutant Arabidopsis plants defective in PTI signaling pathway and MIN7 vesicle-trafficking pathway [208]. This suggests a strong genetic connection between Arabidopsis plants loci (controlling plant defense and cell wall integrity) and phyllospheric bacterial diversity [209]. Mutant rice plants, deficient in jasmonate synthesis, showed a significant reduction in Azoarcus olearius colonization [210]. At the microbiome level, distinct plant genotypes also attract a variable range of disease suppressive and beneficial microbes, and reassemble their microbial diversity via variations in metabolites exuded from roots $[77,211]$. Some bacterial groups belonging to Enterobacter and Kosakonia genera are more abundant in the rhizobiomes of banana cultivars, and provide them a shield against Fusarium wilt [205]. Similarly, bean genotypes significantly affected the microbiome assembly in the rhizosphere, with only $0.7 \%$ operational taxonomic units (OTUs) in common [212]. Strong genetic correlations were detected among the diversity of epiphytic microbial population, maize plants, and their resistance to southern sheath blight pathogen Cochliobolus heterostrophus, and the $\gamma$-aminobutyric acid pathway was responsible for controlling the phyllospheric microbial diversity and southern sheath blight susceptibility in maize [213,214].

Selection and breeding of 'microbe-friendly' cultivars can provide tremendous potential for improved agricultural productivity. Knowledge on beneficial associations between plants and microbes has provided opportunities to manipulate the plant genome to attract and stabilize the functional microbes existing in the microcosm [172]. To achieve this goal, 'designer plants' can be genetically modified to release exudates and hormones that support the recruitment and colonization of beneficial microbiomes. Wild species or relatives may play important roles in exploring genes linked with the assembly of beneficial microbiomes [215]. For example, wild bean accessions had abundant Bacteroidetes, while modern domesticated accessions showed Proteobacteria and Actinobacteria in relatively high abundance [212]. A strong connection between host genotype and associated phylloshperic microbial diversity in different tomato accessions was detected [216]; however, host genetic variations, coupled with environmental factors, were correlated with the endophytic microbial diversity in wheat plants [217]. Thus, it is likely that microbial community shift is linked with modified plant genotypes and altered root morphology. How host genotype-microbiome crosstalk recruits beneficial microbial groups for achieving desirable traits, and how plants modulate and favor the colonization of specific microbiomes need to be investigated to devise ways to maintain functionally active and beneficial microbiomes, as well as to track the real time changes in microbial diversity under field conditions.

\section{Concluding Remarks and Future Perspectives}

Integrated approaches of experimental biology, multi-omics, and computational biology have provided quantitative insights into plant-microbiome interactions and the underlying mechanisms. The broad survey of important crop plants and model plant species has established a list of major fungal and bacterial groups that commonly form associations with plants. However, more studies about microbial diversity are required to discover the functional consortia of microbes for agronomically important crop plants. Systematic approaches to identify core microbiota and their functions in host plants will be required to characterize microbiomes of economic and ecological importance. MWAS and GWAS have predicted key players that contain functional genes for colonizing plants, plant fitness traits, and their influence on the assembly of plant-microbiota. Although these techniques have unraveled the effects of microbiomes on plant fitness under challenging environments, large proportions of variations are not fully understood. Large-scale longitudinal studies are required to develop baseline for plant-microbiome interactions with 
clear consideration of host age and temporal dynamics to elucidate leftover knowledge gaps. Improved understanding about the dynamic interactions of plant-microbiome with challenging environmental conditions will give a way forward to engineer microbial consortia with robust outcomes and predicted behavior. Furthermore, coupling experimental approaches with modelling will accelerate the scientific advancement by resolving methodological and technical challenges associated with the plant-microbiome world. Integrative approaches, combining the knowledge from different scientific disciplines, will help to engineer and boost the activities of complex microbial consortia in a consistent and precise manner. Improved knowledge about the dynamics of plant-microbiome-environment interplay will pave the way for the deployment of engineered microbial consortia for sustainable and improved plant production under a continuously fluctuating environment.

Author Contributions: M.N. conceptualization, manuscript preparation and writing-revision and editing; T.A. figures designing, data collection, writing and editing; U.I. writing and editing; M.S. manuscript reviewing; A. manuscript reviewing; D.L. critical revision of manuscript; I.M. writingrevision and editing and F.S. manuscript preparation, writing-revision and editing, supervision, funding acquisition. All authors have read and agreed to the published version of the manuscript.

Funding: This research was funded by Chinese Agriculture Research System of MOF and MARA of China (CARS-26-11), National Key Research and Development Program of China (No. 2018YFD0201300) and National Natural Science Foundation of China (No. 31871945).

Institutional Review Board Statement: Not applicable.

Informed Consent Statement: Not applicable.

Data Availability Statement: Not applicable.

Acknowledgments: We acknowledge the financial support by the China Agriculture Research System of MOF and MARA of China (CARS-26-11), the National Key Research and Development Program of China (Grant No. 2018YFD0201300), and National Natural Science Foundation of China (No. 31871945). Figures created by using BioRender (https:/ / biorender.com/), accessed date: 13 January 2021.

Conflicts of Interest: The authors declare that they have no known competing financial interests or personal relationships that could have appeared to influence the work reported in this paper.

\begin{abstract}
Abbreviations
AHLs, N-acylhomoserine lactones; AM, arbuscular mycorrhizal; AMC, artificial microbial consortia; Avr, avirulence; BGCs, biosynthetic gene clusters; CERK1, chitin elicitor receptor kinase1; DAPG, 2,4-diacetylphloroglucinol; EF, elongation factor; EFR, EF-Tu receptor; ETI, effector-triggered immunity; FLS2, flagellin-sensitive2; HSL, homoserine lactone; ISR, induced systemic resistance; M/GWAS, metagenome/genome-wide association studies; NRPSs, non-ribosomal peptide synthetases; PAMPs, pathogen-associated molecular patterns, PGPR, plant growth promoting rhizobacteria; PHZ, phenazines; PKSs, polyketide synthases; PRRs, pattern recognition receptors; PTI, PAMP-triggered immunity; $\mathrm{QQ}$, quorum quenching; $\mathrm{QS}$, quorum sensing; TALEs, transcription activation-like effectors; T6SS, type VI secretion system; Xoo, Xanthomonas oryzae pv. oryzae.
\end{abstract}

\title{
References
}

1. Fitzpatrick, C.R.; Copeland, J.; Wang, P.W.; Guttman, D.S.; Kotanen, P.M.; Johnson, M.T. Assembly and ecological function of the root microbiome across angiosperm plant species. Proc. Natl. Acad. Sci. USA 2018, 115, E1157-E1165. [CrossRef]

2. Syed-Ab-Rahman, S.F.; Xiao, Y.; Carvalhais, L.C.; Ferguson, B.J.; Schenk, P.M. Suppression of Phytophthora capsici infection and promotion of tomato growth by soil bacteria. Rhizosphere 2019, 9, 72-75. [CrossRef]

3. Lundberg, D.S.; Lebeis, S.L.; Paredes, S.H.; Yourstone, S.; Gehring, J.; Malfatti, S.; Tremblay, J.; Engelbrektson, A.; Kunin, V.; del Rio, T.G. Defining the core Arabidopsis thaliana root microbiome. Nature 2012, 488, 86-90. [CrossRef] 
4. Coleman-Derr, D.; Desgarennes, D.; Fonseca-Garcia, C.; Gross, S.; Clingenpeel, S.; Woyke, T.; North, G.; Visel, A.; Partida-Martinez, L.P.; Tringe, S.G. Plant compartment and biogeography affect microbiome composition in cultivated and native Agave species. New Phytol. 2016, 209, 798-811. [CrossRef]

5. Hamonts, K.; Trivedi, P.; Garg, A.; Janitz, C.; Grinyer, J.; Holford, P.; Botha, F.C.; Anderson, I.C.; Singh, B.K. Field study reveals core plant microbiota and relative importance of their drivers. Environ. Microbiol. 2018, 20, 124-140. [CrossRef] [PubMed]

6. Xu, J.; Zhang, Y.; Zhang, P.; Trivedi, P.; Riera, N.; Wang, Y.; Liu, X.; Fan, G.; Tang, J.; Coletta-Filho, H.D. The structure and function of the global citrus rhizosphere microbiome. Nat. Commun. 2018, 9, 4894. [CrossRef] [PubMed]

7. Bergelson, J.; Mittelstrass, J.; Horton, M.W. Characterizing both bacteria and fungi improves understanding of the Arabidopsis root microbiome. Sci. Rep. 2019, 9, 24. [CrossRef] [PubMed]

8. Roman-Reyna, V.; Pinili, D.; Borjaa, F.N.; Quibod, I.; Groen, S.C.; Mulyaningsih, E.S.; Rachmat, A.; Slamet-Loedin, I.H.; Alexandrov, N.; Mauleon, R. The rice leaf microbiome has a conserved community structure controlled by complex host-microbe interactions. bioRxiv 2019. [CrossRef]

9. Leach, J.E.; Triplett, L.R.; Argueso, C.T.; Trivedi, P. Communication in the phytobiome. Cell 2017, 169, 587-596. [CrossRef] [PubMed]

10. Fitzpatrick, C.R.; Salas-González, I.; Conway, J.M.; Finkel, O.M.; Gilbert, S.; Russ, D.; Teixeira, P.J.P.L.; Dangl, J.L. The plant microbiome: From ecology to reductionism and beyond. Annu. Rev. Microbiol. 2020, 74, 81-100. [CrossRef] [PubMed]

11. Arif, I.; Batool, M.; Schenk, P.M. Plant microbiome engineering: Expected benefits for improved crop growth and resilience. Trends Biotechnol. 2020, 38, 1385-1396. [CrossRef]

12. Trivedi, P.; Delgado-Baquerizo, M.; Trivedi, C.; Hamonts, K.; Anderson, I.C.; Singh, B.K. Keystone microbial taxa regulate the invasion of a fungal pathogen in agro-ecosystems. Soil Biol. Biochem. 2017, 111, 10-14. [CrossRef]

13. Xiong, C.; Zhu, Y.G.; Wang, J.T.; Singh, B.; Han, L.L.; Shen, J.P.; Li, P.P.; Wang, G.B.; Wu, C.F.; Ge, A.H. Host selection shapes crop microbiome assembly and network complexity. New Phytol. 2020, 229, 1091-1104. [CrossRef]

14. Shade, A.; Jacques, M.-A.; Barret, M. Ecological patterns of seed microbiome diversity, transmission, and assembly. Curr. Opin. Microbiol. 2017, 37, 15-22. [CrossRef]

15. Torres-Cortés, G.; Bonneau, S.; Bouchez, O.; Genthon, C.; Briand, M.; Jacques, M.-A.; Barret, M. Functional microbial features driving community assembly during seed germination and emergence. Front. Plant. Sci. 2018, 9, 902. [CrossRef] [PubMed]

16. Edwards, J.A.; Santos-Medellín, C.M.; Liechty, Z.S.; Nguyen, B.; Lurie, E.; Eason, S.; Phillips, G.; Sundaresan, V. Compositional shifts in root-associated bacterial and archaeal microbiota track the plant life cycle in field-grown rice. PLoS Biol. 2018, 16, e2003862. [CrossRef] [PubMed]

17. Wei, Z.; Gu, Y.; Friman, V.P.; Kowalchuk, G.A.; Xu, Y.; Shen, Q.; Jousset, A. Initial soil microbiome composition and functioning predetermine future plant health. Sci. Adv. 2019, 5, eaaw0759. [CrossRef]

18. De Souza, R.S.C.; Okura, V.K.; Armanhi, J.S.L.; Jorrín, B.; Lozano, N.; Da Silva, M.J.; González-Guerrero, M.; De Araújo, L.M.; Verza, N.C.; Bagheri, H.C. Unlocking the bacterial and fungal communities assemblages of sugarcane microbiome. Sci. Rep. 2016, 6, 28774. [CrossRef] [PubMed]

19. Cregger, M.; Veach, A.; Yang, Z.; Crouch, M.; Vilgalys, R.; Tuskan, G.; Schadt, C. The Populus holobiont: Dissecting the effects of plant niches and genotype on the microbiome. Microbiome 2018, 6, 31. [CrossRef]

20. Tian, B.; Zhang, C.; Ye, Y.; Wen, J.; Wu, Y.; Wang, H.; Li, H.; Cai, S.; Cai, W.; Cheng, Z. Beneficial traits of bacterial endophytes belonging to the core communities of the tomato root microbiome. Agric. Ecosyst. Environ. 2017, 247, 149-156. [CrossRef]

21. Soni, R.; Suyal, D.C.; Sahu, B.; Phulara, S.C. Metagenomics: An approach to unravel the plant microbiome and its function. In Phytomicrobiome Interactions and Sustainable Agriculture; Verma, A., Saini, J.K., Hesham, A.E.-L., Singh, H.B., Eds.; Wiley-Blackwell: Hoboken, NJ, USA, 2021; pp. 32-44.

22. Compant, S.; Samad, A.; Faist, H.; Sessitsch, A. A review on the plant microbiome: Ecology, functions, and emerging trends in microbial application. J. Adv. Res. 2019, 19, 29-37. [CrossRef] [PubMed]

23. Schlaeppi, K.; Bulgarelli, D. The plant microbiome at work. MPMI 2015, 28, 212-217. [CrossRef] [PubMed]

24. Hardoim, P.R.; Van Overbeek, L.S.; Berg, G.; Pirttilä, A.M.; Compant, S.; Campisano, A.; Döring, M.; Sessitsch, A. The hidden world within plants: Ecological and evolutionary considerations for defining functioning of microbial endophytes. Microbiol. Mol. Biol. Rev. 2015, 79, 293-320. [CrossRef] [PubMed]

25. Finkel, O.M.; Salas-González, I.; Castrillo, G.; Spaepen, S.; Law, T.F.; Teixeira, P.J.P.L.; Jones, C.D.; Dangl, J.L. The effects of soil phosphorus content on plant microbiota are driven by the plant phosphate starvation response. PLoS Biol. 2019, 17, e3000534. [CrossRef]

26. Zhang, Q.; Acuña, J.J.; Inostroza, N.G.; Mora, M.L.; Radic, S.; Sadowsky, M.J.; Jorquera, M.A. Endophytic bacterial communities associated with roots and leaves of plants growing in Chilean extreme environments. Sci. Rep. 2019, 9, 4950. [CrossRef] [PubMed]

27. Fouda, A.; Eid, A.M.; Elsaied, A.; El-Belely, E.F.; Barghoth, M.G.; Azab, E.; Gobouri, A.A.; Hassan, S.E.-D. Plant growth-promoting endophytic bacterial community inhabiting the leaves of Pulicaria incisa (Lam.) DC inherent to arid regions. Plants 2021, 10, 76. [CrossRef] [PubMed]

28. Vorholt, J.A. Microbial life in the phyllosphere. Nat. Rev. Microbiol. 2012, 10, 828-840. [CrossRef]

29. Zarraonaindia, I.; Owens, S.M.; Weisenhorn, P.; West, K.; Hampton-Marcell, J.; Lax, S.; Bokulich, N.A.; Mills, D.A.; Martin, G.; Taghavi, S. The soil microbiome influences grapevine-associated microbiota. mBio 2015, 6, e02527-14. [CrossRef] 
30. Wallace, J.G.; Kremling, K.A.; Kovar, L.L.; Buckler, E.S. Quantitative genetics of the maize leaf microbiome. Phytobiomes J. 2018, 2, 208-224. [CrossRef]

31. Bulgarelli, D.; Rott, M.; Schlaeppi, K.; van Themaat, E.V.L.; Ahmadinejad, N.; Assenza, F.; Rauf, P.; Huettel, B.; Reinhardt, R.; Schmelzer, E. Revealing structure and assembly cues for Arabidopsis root-inhabiting bacterial microbiota. Nature 2012, 488, 91-95. [CrossRef]

32. Wagner, M.R.; Lundberg, D.S.; Tijana, G.; Tringe, S.G.; Dangl, J.L.; Mitchell-Olds, T. Host genotype and age shape the leaf and root microbiomes of a wild perennial plant. Nat. Commun. 2016, 7, 12151. [CrossRef]

33. Kecskeméti, E.; Berkelmann-Löhnertz, B.; Reineke, A. Are epiphytic microbial communities in the carposphere of ripening grape clusters (Vitis vinifera L.) different between conventional, organic, and biodynamic grapes? PLoS ONE 2016, 11, e0160852. [CrossRef] [PubMed]

34. Steven, B.; Huntley, R.B.; Zeng, Q. The influence of flower anatomy and apple cultivar on the apple flower phytobiome. Phytobiomes 2018, 2, 171-179. [CrossRef]

35. Aleklett, K.; Hart, M.; Shade, A. The microbial ecology of flowers: An emerging frontier in phyllosphere research. Botany 2014, 92, 253-266. [CrossRef]

36. Griffiths, S.M.; Galambao, M.; Rowntree, J.; Goodhead, I.; Hall, J.; O’Brien, D.; Atkinson, N.; Antwis, R.E. Complex associations between cross-kingdom microbial endophytes and host genotype in ash dieback disease dynamics. J. Ecol. 2020, 108, 291-309. [CrossRef]

37. Morelli, M.; Bahar, O.; Papadopoulou, K.K.; Hopkins, D.L.; Obradović, A. Role of endophytes in plant health and defense against pathogens. Front. Plant. Sci. 2020, 11, 1312. [CrossRef] [PubMed]

38. Yang, F.; Zhang, J.; Zhang, H.; Ji, G.; Zeng, L.; Li, Y.; Yu, C.; Fernando, W.D.; Chen, W. Bacterial blight induced shifts in endophytic microbiome of rice leaves and the enrichment of specific bacterial strains with pathogen antagonism. Front. Plant. Sci. 2020, 11, 963. [CrossRef] [PubMed]

39. Cordovez, V.; Dini-Andreote, F.; Carrión, V.J.; Raaijmakers, J.M. Ecology and evolution of plant microbiomes. Annu. Rev. Microbiol. 2019, 73, 69-88. [CrossRef]

40. Van der Heijden, M.G.; Hartmann, M. Networking in the plant microbiome. PLoS Biol. 2016, 14, e1002378. [CrossRef]

41. O'Neal, L.; Vo, L.; Alexandre, G. Specific root exudates compounds sensed by dedicated chemoreceptors shape Azospirillum brasilense chemotaxis in the rhizosphere. Appl. Environ. Microbiol. 2020, 86, e01026-20. [CrossRef]

42. Zhang, J.; Liu, Y.-X.; Zhang, N.; Hu, B.; Jin, T.; Xu, H.; Qin, Y.; Yan, P.; Zhang, X.; Guo, X. NRT1.1B is associated with root microbiota composition and nitrogen use in field-grown rice. Nat. Biotechnol. 2019, 37, 676-684. [CrossRef] [PubMed]

43. Zhang, Y.; Xu, J.; Riera, N.; Jin, T.; Li, J.; Wang, N. Huanglongbing impairs the rhizosphere-to-rhizoplane enrichment process of the citrus root-associated microbiome. Microbiome 2017, 5, 97. [CrossRef] [PubMed]

44. Levy, A.; Gonzalez, I.S.; Mittelviefhaus, M.; Clingenpeel, S.; Paredes, S.H.; Miao, J.; Wang, K.; Devescovi, G.; Stillman, K.; Monteiro, F. Genomic features of bacterial adaptation to plants. Nat. Genet. 2018, 50, 138-150. [CrossRef] [PubMed]

45. Bai, Y.; Müller, D.B.; Srinivas, G.; Garrido-Oter, R.; Potthoff, E.; Rott, M.; Dombrowski, N.; Münch, P.C.; Spaepen, S.; RemusEmsermann, M. Functional overlap of the Arabidopsis leaf and root microbiota. Nature 2015, 528, 364-369. [CrossRef] [PubMed]

46. Bacilio-Jiménez, M.; Aguilar-Flores, S.; Ventura-Zapata, E.; Pérez-Campos, E.; Bouquelet, S.; Zenteno, E. Chemical characterization of root exudates from rice (Oryza sativa) and their effects on the chemotactic response of endophytic bacteria. Plant. Soil 2003, 249, 271-277. [CrossRef]

47. Kumar, R.; Bhatia, R.; Kukreja, K.; Behl, R.K.; Dudeja, S.S.; Narula, N. Establishment of Azotobacter on plant roots: Chemotactic response, development and analysis of root exudates of cotton (Gossypium hirsutum L.) and wheat (Triticum aestivum L.). J. Basic Microbiol. 2007, 47, 436-439. [CrossRef] [PubMed]

48. Feng, H.; Zhang, N.; Du, W.; Zhang, H.; Liu, Y.; Fu, R.; Shao, J.; Zhang, G.; Shen, Q.; Zhang, R. Identification of chemotaxis compounds in root exudates and their sensing chemoreceptors in plant-growth-promoting rhizobacteria Bacillus amyloliquefaciens SQR9. MPMI 2018, 31, 995-1005. [CrossRef]

49. Mandal, S.M.; Chakraborty, D.; Dey, S. Phenolic acids act as signaling molecules in plant-microbe symbioses. Plant. Signal. Behav. 2010, 5, 359-368. [CrossRef]

50. Dennis, P.G.; Miller, A.J.; Hirsch, P.R. Are root exudates more important than other sources of rhizodeposits in structuring rhizosphere bacterial communities? FEMS Microbiol. Ecol. 2010, 72, 313-327. [CrossRef]

51. Sharma, M.; Saleh, D.; Charron, J.-B.; Jabaji, S. A crosstalk between Brachypodium root exudates, organic acids, and Bacillus velezensis B26, a growth promoting bacterium. Front. Microbiol. 2020, 11, 575578. [CrossRef]

52. Walker, T.S.; Bais, H.P.; Grotewold, E.; Vivanco, J.M. Root exudation and rhizosphere biology. Plant. Physiol. 2003, 132, 44-51. [CrossRef]

53. Sampedro, I.; Parales, R.E.; Krell, T.; Hill, J.E. Pseudomonas chemotaxis. FEMS Microbiol. Rev. 2015, 39, 17-46.

54. Scharf, B.E.; Hynes, M.F.; Alexandre, G.M. Chemotaxis signaling systems in model beneficial plant-bacteria associations. Plant. Mol. Biol. Rep. 2016, 90, 549-559. [CrossRef]

55. Ankati, S.; Podile, A.R. Metabolites in the root exudates of groundnut change during interaction with plant growth promoting rhizobacteria in a strain-specific manner. J. Plant. Physiol. 2019, 243, 153057. [CrossRef] 
56. Cesari, A.; Paulucci, N.; López-Gómez, M.; Hidalgo-Castellanos, J.; Plá, C.L.; Dardanelli, M.S. Restrictive water condition modifies the root exudates composition during peanut-PGPR interaction and conditions early events, reversing the negative effects on plant growth. Plant. Physiol. Biochem. 2019, 142, 519-527. [CrossRef]

57. Liu, C.-W.; Murray, J.D. The role of flavonoids in nodulation host-range specificity: An update. Plants 2016, 5, 33. [CrossRef]

58. Garrido-Oter, R.; Nakano, R.T.; Dombrowski, N.; Ma, K.-W.; Team, T.A.; McHardy, A.C.; Schulze-Lefert, P. Modular traits of the Rhizobiales root microbiota and their evolutionary relationship with symbiotic rhizobia. Cell Host Microbe 2018, $24,155-167$. [CrossRef]

59. Jiménez Bremont, J.F.; Marina, M.; Guerrero-Gonzalez, M.d.1.L.; Rossi, F.R.; Sánchez-Rangel, D.; Rodríguez-Kessler, M.; Ruiz, O.A.; Gárriz, A. Physiological and molecular implications of plant polyamine metabolism during biotic interactions. Front. Plant. Sci. 2014, 5, 95. [CrossRef] [PubMed]

60. Liu, Z.; Beskrovnaya, P.; Melnyk, R.A.; Hossain, S.S.; Khorasani, S.; O'Sullivan, L.R.; Wiesmann, C.L.; Bush, J.; Richard, J.D.; Haney, C.H. A genome-wide screen identifies genes in rhizosphere-associated Pseudomonas required to evade plant defenses. mBio 2018, 9, e00433-18. [CrossRef] [PubMed]

61. Saleh, D.; Sharma, M.; Seguin, P.; Jabaji, S. Organic acids and root exudates of Brachypodium distachyon: Effects on chemotaxis and biofilm formation of endophytic bacteria. Can. J. Microbiol. 2020, 66, 562-575. [CrossRef] [PubMed]

62. Blair, P.M.; Land, M.L.; Piatek, M.J.; Jacobson, D.A.; Lu, T.-Y.S.; Doktycz, M.J.; Pelletier, D.A. Exploration of the biosynthetic potential of the Populus microbiome. mSystems 2018, 3, e00045-18. [CrossRef]

63. Kwak, M.-J.; Kong, H.G.; Choi, K.; Kwon, S.-K.; Song, J.Y.; Lee, J.; Lee, P.A.; Choi, S.Y.; Seo, M.; Lee, H.J. Rhizosphere microbiome structure alters to enable wilt resistance in tomato. Nat. Biotechnol. 2018, 36, 1100-1109. [CrossRef] [PubMed]

64. Mendes, L.W.; Raaijmakers, J.M.; de Hollander, M.; Mendes, R.; Tsai, S.M. Influence of resistance breeding in common bean on rhizosphere microbiome composition and function. ISME J. 2018, 12, 212-224. [CrossRef] [PubMed]

65. Carrión, V.J.; Perez-Jaramillo, J.; Cordovez, V.; Tracanna, V.; De Hollander, M.; Ruiz-Buck, D.; Mendes, L.W.; van Ijcken, W.F.; Gomez-Exposito, R.; Elsayed, S.S. Pathogen-induced activation of disease-suppressive functions in the endophytic root microbiome. Science 2019, 366, 606-612. [CrossRef] [PubMed]

66. Helfrich, E.J.; Vogel, C.M.; Ueoka, R.; Schäfer, M.; Ryffel, F.; Müller, D.B.; Probst, S.; Kreuzer, M.; Piel, J.; Vorholt, J.A. Bipartite interactions, antibiotic production and biosynthetic potential of the Arabidopsis leaf microbiome. Nat. Microbiol. 2018, 3, 909-919. [CrossRef] [PubMed]

67. De Vries, S.; Stukenbrock, E.H.; Rose, L.E. Rapid evolution in plant-microbe interactions-An evolutionary genomics perspective. New Phytol. 2020, 226, 1256-1262. [CrossRef]

68. Rutherford, S.T.; Bassler, B.L. Bacterial quorum sensing: Its role in virulence and possibilities for its control. Cold Spring Harb. Perspect. Med. 2012, 2, a012427. [CrossRef] [PubMed]

69. Balasubramanian, V.K.; Jansson, C.; Baker, S.E.; Ahkami, A.H. Molecular mechanisms of plant-microbe interactions in the rhizosphere as targets for improving plant productivity. In Rhizosphere Biology: Interactions between Microbes and Plants; Gupta, V., Sharma, A., Eds.; Springer: Singapore, 2020; pp. 295-338.

70. Mousa, W.K.; Shearer, C.; Limay-Rios, V.; Ettinger, C.L.; Eisen, J.A.; Raizada, M.N. Root-hair endophyte stacking in finger millet creates a physicochemical barrier to trap the fungal pathogen Fusarium graminearum. Nat. Microbiol. 2016, 1, 16167. [CrossRef] [PubMed]

71. Chagas, F.O.; de Cassia Pessotti, R.; Caraballo-Rodriguez, A.M.; Pupo, M.T. Chemical signaling involved in plant-microbe interactions. Chem. Soc. Rev. 2018, 47, 1652-1704. [CrossRef]

72. Khanna, K.; Jamwal, V.L.; Kohli, S.K.; Gandhi, S.G.; Ohri, P.; Bhardwaj, R.; Wijaya, L.; Alyemeni, M.N.; Ahmad, P. Role of plant growth promoting bacteria (PGPRs) as biocontrol agents of Meloidogyne incognita through improved plant defense of Lycopersicon esculentum. Plant. Soil 2019, 436, 325-345. [CrossRef]

73. Schmidt, R.; de Jager, V.; Zühlke, D.; Wolff, C.; Bernhardt, J.; Cankar, K.; Beekwilder, J.; van Ijcken, W.; Sleutels, F.; De Boer, W. Fungal volatile compounds induce production of the secondary metabolite Sodorifen in Serratia plymuthica PRI-2C. Sci. Rep. 2017, 7, 862. [CrossRef]

74. Korenblum, E.; Dong, Y.; Szymanski, J.; Panda, S.; Jozwiak, A.; Massalha, H.; Meir, S.; Rogachev, I.; Aharoni, A. Rhizosphere microbiome mediates systemic root metabolite exudation by root-to-root signaling. Proc. Natl. Acad. Sci. USA 2020, 117, 3874-3883. [CrossRef] [PubMed]

75. Trivedi, P.; Leach, J.E.; Tringe, S.G.; Sa, T.; Singh, B.K. Plant-microbiome interactions: From community assembly to plant health. Nat. Rev. Microbiol. 2020, 18, 607-621. [CrossRef]

76. Kalia, V.C.; Gong, C.; Patel, S.K.; Lee, J.-K. Regulation of plant mineral nutrition by signal molecules. Microorganisms 2021, 9, 774. [CrossRef] [PubMed]

77. Rodríguez, M.; Torres, M.; Blanco, L.; Béjar, V.; Sampedro, I.; Llamas, I. Plant growth-promoting activity and quorum quenchingmediated biocontrol of bacterial phytopathogens by Pseudomonas segetis strain P6. Sci. Rep. 2020, 10, 4121. [CrossRef] [PubMed]

78. Grandclément, C.; Tannières, M.; Moréra, S.; Dessaux, Y.; Faure, D. Quorum quenching: Role in nature and applied developments. FEMS Microbiol. Rev. 2016, 40, 86-116. [CrossRef] [PubMed]

79. Uroz, S.; Dessaux, Y.; Oger, P. Quorum sensing and quorum quenching: The yin and yang of bacterial communication. ChemBioChem 2009, 10, 205-216. [CrossRef] [PubMed] 
80. Kalia, V.C.; Patel, S.K.; Kang, Y.C.; Lee, J.-K. Quorum sensing inhibitors as antipathogens: Biotechnological applications. Biotechnol. Adv. 2019, 37, 68-90. [CrossRef]

81. Kalia, V.C.; Purohit, H.J. Quenching the quorum sensing system: Potential antibacterial drug targets. Crit. Rev. Microbiol. 2011, 37, 121-140. [CrossRef] [PubMed]

82. Kalia, V.C. Quorum sensing inhibitors: An overview. Biotechnol. Adv. 2013, 31, 224-245. [CrossRef]

83. Hida, A.; Oku, S.; Miura, M.; Matsuda, H.; Tajima, T.; Kato, J. Characterization of methyl-accepting chemotaxis proteins (MCPs) for amino acids in plant-growth-promoting rhizobacterium Pseudomonas protegens $\mathrm{CHA} 0$ and enhancement of amino acid chemotaxis by MCP genes overexpression. Biosci. Biotechnol. Biochem. 2020, 84, 1948-1957. [CrossRef] [PubMed]

84. Liu, H.; Brettell, L.E.; Qiu, Z.; Singh, B.K. Microbiome-mediated stress resistance in plants. Trends Plant Sci. 2020, $25,733-743$. [CrossRef] [PubMed]

85. Shrestha, M.; Compton, K.K.; Mancl, J.M.; Webb, B.A.; Brown, A.M.; Scharf, B.E.; Schubot, F.D. Structure of the sensory domain of McpX from Sinorhizobium meliloti, the first known bacterial chemotactic sensor for quaternary ammonium compounds. Biochem. J. 2018, 475, 3949-3962. [CrossRef]

86. Webb, B.A.; Compton, K.K.; del Campo, J.S.M.; Taylor, D.; Sobrado, P.; Scharf, B.E. Sinorhizobium meliloti chemotaxis to multiple amino acids is mediated by the chemoreceptor McpU. MPMI 2017, 30, 770-777. [CrossRef] [PubMed]

87. Rudrappa, T.; Czymmek, K.J.; Paré, P.W.; Bais, H.P. Root-secreted malic acid recruits beneficial soil bacteria. Plant Physiol. 2008, 148, 1547-1556. [CrossRef] [PubMed]

88. Rekha, K.; Baskar, B.; Srinath, S.; Usha, B. Plant-growth-promoting rhizobacteria Bacillus subtilis RR4 isolated from rice rhizosphere induces malic acid biosynthesis in rice roots. Can. J. Microbiol. 2018, 64, 20-27. [CrossRef] [PubMed]

89. De Weert, S.; Vermeiren, H.; Mulders, I.H.; Kuiper, I.; Hendrickx, N.; Bloemberg, G.V.; Vanderleyden, J.; De Mot, R.; Lugtenberg, B.J. Flagella-driven chemotaxis towards exudate components is an important trait for tomato root colonization by Pseudomonas fluorescens. MPMI 2002, 15, 1173-1180. [CrossRef] [PubMed]

90. Watts, K.J.; Vaknin, A.; Fuqua, C.; Kazmierczak, B.I. New twists and turns in bacterial locomotion and signal transduction. J. Bacteriol. 2019, 201, e00439-19. [CrossRef] [PubMed]

91. Ma, L.; Zheng, S.C.; Zhang, T.K.; Liu, Z.Y.; Wang, X.J.; Zhou, X.K.; Yang, C.G.; Duo, J.L.; Mo, M.H. Effect of nicotine from tobacco root exudates on chemotaxis, growth, biocontrol efficiency, and colonization by Pseudomonas aeruginosa NXHG29. Antonie Van Leeuwenhoek 2018, 111, 1237-1257. [CrossRef]

92. Liu, H.; Khan, M.Y.; Carvalhais, L.C.; Delgado-Baquerizo, M.; Yan, L.; Crawford, M.; Dennis, P.G.; Singh, B.; Schenk, P.M. Soil amendments with ethylene precursor alleviate negative impacts of salinity on soil microbial properties and productivity. Sci. Rep. 2019, 9, 6892. [CrossRef]

93. Li, P.; Ma, L.; Feng, Y.L.; Mo, M.H.; Yang, F.X.; Dai, H.F.; Zhao, Y.X. Diversity and chemotaxis of soil bacteria with antifungal activity against Fusarium wilt of banana. J. Ind. Microbiol. 2012, 39, 1495-1505. [CrossRef] [PubMed]

94. Jin, Y.; Zhu, H.; Luo, S.; Yang, W.; Zhang, L.; Li, S.; Jin, Q.; Cao, Q.; Sun, S.; Xiao, M. Role of maize root exudates in promotion of colonization of Bacillus velezensis strain S3-1 in rhizosphere soil and root tissue. Curr. Microbiol. 2019, 76, 855-862. [CrossRef]

95. Jiang, N.; Liu, W.; Li, Y.; Wu, H.; Zhang, Z.; Alexandre, G.; Elmerich, C.; Xie, Z. A chemotaxis receptor modulates nodulation during the Azorhizobium caulinodans-Sesbania rostrata symbiosis. Appl. Environ. Microbiol. 2016, 82, 3174-3184. [CrossRef]

96. Li, X.; Hu, H.-J.; Li, J.-Y.; Wang, C.; Chen, S.-L.; Yan, S.-Z. Effects of the endophytic bacteria Bacillus cereus BCM2 on tomato root exudates and Meloidogyne incognita infection. Plant. Dis. 2019, 103, 1551-1558. [CrossRef]

97. Russell, A.B.; Peterson, S.B.; Mougous, J.D. Type VI secretion system effectors: Poisons with a purpose. Nat. Rev. Microbiol. 2014, 12, 137-148. [CrossRef] [PubMed]

98. Ofek-Lalzar, M.; Sela, N.; Goldman-Voronov, M.; Green, S.J.; Hadar, Y.; Minz, D. Niche and host-associated functional signatures of the root surface microbiome. Nat. Commun. 2014, 5, 1-9. [CrossRef]

99. Bulgarelli, D.; Garrido-Oter, R.; Münch, P.C.; Weiman, A.; Dröge, J.; Pan, Y.; McHardy, A.C.; Schulze-Lefert, P. Structure and function of the bacterial root microbiota in wild and domesticated barley. Cell Host Microbe 2015, 17, 392-403. [CrossRef]

100. Carlström, C.I.; Field, C.M.; Bortfeld-Miller, M.; Müller, B.; Sunagawa, S.; Vorholt, J.A. Synthetic microbiota reveal priority effects and keystone strains in the Arabidopsis phyllosphere. Nat. Ecol. Evol. 2019, 3, 1445-1454. [CrossRef]

101. Chhabra, R.; Kaur, S.; Vij, L.; Gaur, K. Exploring physiological and biochemical factors governing plant pathogen interaction: A review. Int. J. Curr. Microbiol. App. Sci. 2020, 9, 1650-1666. [CrossRef]

102. Boyd, L.A.; Ridout, C.; O'Sullivan, D.M.; Leach, J.E.; Leung, H. Plant-pathogen interactions: Disease resistance in modern agriculture. Trends Genet. 2013, 29, 233-240. [CrossRef]

103. Peyraud, R.; Dubiella, U.; Barbacci, A.; Genin, S.; Raffaele, S.; Roby, D. Advances on plant-pathogen interactions from molecular toward systems biology perspectives. Plant. J. 2017, 90, 720-737. [CrossRef]

104. Seybold, H.; Demetrowitsch, T.J.; Hassani, M.A.; Szymczak, S.; Reim, E.; Haueisen, J.; Lübbers, L.; Rühlemann, M.; Franke, A.; Schwarz, K. A fungal pathogen induces systemic susceptibility and systemic shifts in wheat metabolome and microbiome composition. Nat. Commun. 2020, 11, 1910. [CrossRef]

105. Singh, A.; Singh, I.K. Molecular Aspects of Plant-Pathogen Interaction; Springer: Singapore, 2018; Volume 10.

106. Pathma, J.; Raman, G.; Kennedy, R.K.; Bhushan, L.S. Recent advances in plant-microbe interaction. In Microbial Diversity, Interventions and Scope; Sharma, S., Sharma, N., Sharma, M., Eds.; Springer: Singapore, 2020; pp. $23-49$.

107. Zipfel, C.; Oldroyd, G.E. Plant signalling in symbiosis and immunity. Nature 2017, 543, 328-336. [CrossRef] 
108. Gupta, R.; Lee, S.E.; Agrawal, G.K.; Rakwal, R.; Park, S.; Wang, Y.; Kim, S.T. Understanding the plant-pathogen interactions in the context of proteomics-generated apoplastic proteins inventory. Front. Plant. Sci. 2015, 6, 352. [CrossRef] [PubMed]

109. Teixeira, P.J.P.; Colaianni, N.R.; Fitzpatrick, C.R.; Dangl, J.L. Beyond pathogens: Microbiota interactions with the plant immune system. Curr. Opin. Microbiol. 2019, 49, 7-17. [CrossRef] [PubMed]

110. Jones, J.D.; Dangl, J.L. The plant immune system. Nature 2006, 444, 323-329. [CrossRef] [PubMed]

111. Gao, M.; Xiong, C.; Gao, C.; Tsui, C.K.; Zhou, X.; Wang, M.-M.; Zhang, A.-M.; Cai, L. Disease-induced changes in plant microbiome assembly and functional adaptation. Res. Seq. 2020. [CrossRef]

112. Musonerimana, S.; Bez, C.; Licastro, D.; Habarugira, G.; Bigirimana, J.; Venturi, V. Pathobiomes revealed that Pseudomonas fuscovaginae and Sarocladium oryzae are independently associated with rice sheath rot. Microb. Ecol. 2020, 80, 627-642. [CrossRef]

113. Berg, G.; Rybakova, D.; Grube, M.; Köberl, M. The plant microbiome explored: Implications for experimental botany. J. Exp. Bot. 2016, 67, 995-1002. [CrossRef] [PubMed]

114. Prashar, P.; Kapoor, N.; Sachdeva, S. Rhizosphere: Its structure, bacterial diversity and significance. Rev. Environ. Sci. Biotechnol. 2014, 13, 63-77. [CrossRef]

115. Olanrewaju, O.S.; Glick, B.R.; Babalola, O.O. Mechanisms of action of plant growth promoting bacteria. World J. Microbiol. Biotechnol. 2017, 33, 197. [CrossRef] [PubMed]

116. Babalola, O.O.; Fadiji, A.E.; Enagbonma, B.J.; Alori, E.T.; Ayilara, M.S.; Ayangbenro, A.S. The nexus between plant and plant microbiome: Revelation of the networking strategies. Front. Microbiol. 2020, 11, 2128. [CrossRef] [PubMed]

117. Sergaki, C.; Lagunas, B.; Lidbury, I.; Gifford, M.L.; Schäfer, P. Challenges and approaches in microbiome research: From fundamental to applied. Front. Plant. Sci. 2018, 9, 1205. [CrossRef]

118. Berg, M.; Koskella, B. Nutrient-and dose-dependent microbiome-mediated protection against a plant pathogen. Curr. Biol. 2018, 28, 2487-2492. [CrossRef]

119. Ravanbakhsh, M.H.; Kowalchuk, G.A.; Jousset, A. Root-associated microorganisms reprogram plant life history along the growth-stress resistance tradeoff. ISME J. 2019, 13, 3093-3101. [CrossRef] [PubMed]

120. Jain, S.; Jain, J.; Singh, J. The rhizosphere microbiome: Microbial communities and plant health. In Plant Microbiome Paradigm; Varma, A., Tripathi, S., Prasad, R., Eds.; Springer: Cham, Germany, 2020; pp. 175-190.

121. Ritpitakphong, U.; Falquet, L.; Vimoltust, A.; Berger, A.; Métraux, J.P.; L'Haridon, F. The microbiome of the leaf surface of Arabidopsis protects against a fungal pathogen. New Phytol. 2016, 210, 1033-1043. [CrossRef]

122. Okubara, P.A.; Paulitz, T.C. Root defense responses to fungal pathogens: A molecular perspective. In Root Physiology: From Gene to Function; Lambers, H., Colmer, T., Eds.; Springer: Dordrecht, The Netherlands, 2005; pp. 215-226.

123. De Coninck, B.; Timmermans, P.; Vos, C.; Cammue, B.P.; Kazan, K. What lies beneath: Belowground defense strategies in plants. Trends Plant. Sci. 2015, 20, 91-101. [CrossRef]

124. Qu, Q.; Zhang, Z.; Peijnenburg, W.; Liu, W.; Lu, T.; Hu, B.; Chen, J.; Chen, J.; Lin, Z.; Qian, H. Rhizosphere microbiome assembly and its impact on plant growth. J. Agric. Food Chem. 2020, 68, 5024-5038. [CrossRef]

125. Gonzalez, M.; Pujol, M.; Metraux, J.P.; Gonzalez-Garcia, V.; Bolton, M.D.; Borrás-Hidalgo, O. Tobacco leaf spot and root rot caused by Rhizoctonia solani Kühn. Mol. Plant Pathol. 2011, 12, 209-216. [CrossRef] [PubMed]

126. Michielse, C.B.; Rep, M. Pathogen profile update: Fusarium oxysporum. Mol. Plant. Pathol. 2009, 10, 311-324. [CrossRef]

127. Klosterman, S.J.; Atallah, Z.K.; Vallad, G.E.; Subbarao, K.V. Diversity, pathogenicity, and management of Verticillium species. Annu. Rev. Phytopathol. 2009, 47, 39-62. [CrossRef] [PubMed]

128. Hao, W.-Y.; Ren, L.-X.; Ran, W.; Shen, Q.-R. Allelopathic effects of root exudates from watermelon and rice plants on Fusarium oxysporum f. sp. niveum. Plant Soil 2010, 336, 485-497. [CrossRef]

129. Turrà, D.; el Ghalid, M.; Rossi, F.; di Pietro, A. Fungal pathogen uses sex pheromone receptor for chemotropic sensing of host plant signals. Nature 2015, 527, 521-524. [CrossRef]

130. Katan, J. Diseases caused by soilborne pathogens: Biology, management and challenges. J. Plant. Pathol. 2017, 99, 305-315.

131. Andrighetti, T.; Bohar, B.; Lemke, N.; Sudhakar, P.; Korcsmaros, T. MicrobioLink: An integrated computational pipeline to infer functional effects of microbiome-host interactions. Cells 2020, 9, 1278. [CrossRef]

132. Antoniou, A.; Tsolakidou, M.-D.; Stringlis, I.A.; Pantelides, I.S. Rhizosphere microbiome recruited from a suppressive compost improves plant fitness and increases protection against vascular wilt pathogens of tomato. Front. Plant. Sci. 2017, 8, 2022. [CrossRef]

133. Anand, A.; Uppalapati, S.R.; Ryu, C.M.; Allen, S.N.; Kang, L.; Tang, Y.; Mysore, K.S. Salicylic acid and systemic acquired resistance play a role in attenuating crown gall disease caused by Agrobacterium tumefaciens. Plant. Physiol. 2008, 146, 703-715. [CrossRef]

134. Peeters, N.; Guidot, A.; Vailleau, F.; Valls, M. Ralstonia solanacearum, a widespread bacterial plant pathogen in the post-genomic era. Mol. Plant Pathol. 2013, 14, 651-662. [CrossRef]

135. Barelli, L.; Waller, A.S.; Behie, S.W.; Bidochka, M.J. Plant microbiome analysis after Metarhizium amendment reveals increases in abundance of plant growth-promoting organisms and maintenance of disease-suppressive soil. PLoS ONE 2020, 15, e0231150. [CrossRef]

136. Snelders, N.C.; Kettles, G.J.; Rudd, J.J.; Thomma, B.P. Plant pathogen effector proteins as manipulators of host microbiomes? Mol. Plant Pathol. 2018, 19, 257. [CrossRef]

137. Pieterse, C.M.; Zamioudis, C.; Berendsen, R.L.; Weller, D.M.; Van Wees, S.C.; Bakker, P.A. Induced systemic resistance by beneficial microbes. Annu. Rev. Phytopathol. 2014, 52, 347-375. [CrossRef] [PubMed] 
138. Backer, R.; Rokem, J.S.; Ilangumaran, G.; Lamont, J.; Praslickova, D.; Ricci, E.; Subramanian, S.; Smith, D.L. Plant growthpromoting rhizobacteria: Context, mechanisms of action, and roadmap to commercialization of biostimulants for sustainable agriculture. Front. Plant Sci. 2018, 9, 1473. [CrossRef]

139. Durán, P.; Thiergart, T.; Garrido-Oter, R.; Agler, M.; Kemen, E.; Schulze-Lefert, P.; Hacquard, S. Microbial interkingdom interactions in roots promote Arabidopsis survival. Cell 2018, 175, 973-983. [CrossRef] [PubMed]

140. Penton, C.R.; Gupta, V.; Tiedje, J.M.; Neate, S.M.; Ophel-Keller, K.; Gillings, M.; Harvey, P.; Pham, A.; Roget, D.K. Fungal community structure in disease suppressive soils assessed by 28S LSU gene sequencing. PLoS ONE 2014, 9, e93893. [CrossRef] [PubMed]

141. Cha, J.-Y.; Han, S.; Hong, H.-J.; Cho, H.; Kim, D.; Kwon, Y.; Kwon, S.-K.; Crüsemann, M.; Lee, Y.B.; Kim, J.F. Microbial and biochemical basis of a Fusarium wilt-suppressive soil. ISME J. 2016, 10, 119-129. [CrossRef] [PubMed]

142. Hol, W.G.; Garbeva, P.; Hordijk, C.; Hundscheid, M.P.; Gunnewiek, P.J.K.; Van Agtmaal, M.; Kuramae, E.E.; De Boer, W. Non-random species loss in bacterial communities reduces antifungal volatile production. Ecology 2015, 96, 2042-2048. [CrossRef]

143. Carrión, V.J.; Cordovez, V.; Tyc, O.; Etalo, D.W.; de Bruijn, I.; de Jager, V.C.; Medema, M.H.; Eberl, L.; Raaijmakers, J.M. Involvement of Burkholderiaceae and sulfurous volatiles in disease-suppressive soils. ISME J. 2018, 12, 2307-2321. [CrossRef]

144. Gómez Expósito, R.; de Bruijn, I.; Postma, J.; Raaijmakers, J.M. Current insights into the role of rhizosphere bacteria in disease suppressive soils. Front. Microbiol. 2017, 8, 2529. [CrossRef]

145. Raaijmakers, J.M.; Mazzola, M. Diversity and natural functions of antibiotics produced by beneficial and plant pathogenic bacteria. Annu. Rev. Phytopathol. 2012, 50, 403-424. [CrossRef]

146. Mazurier, S.; Corberand, T.; Lemanceau, P.; Raaijmakers, J.M. Phenazine antibiotics produced by fluorescent pseudomonads contribute to natural soil suppressiveness to Fusarium wilt. ISME J. 2009, 3, 977-991. [CrossRef]

147. Latz, E.; Eisenhauer, N.; Rall, B.C.; Allan, E.; Roscher, C.; Scheu, S.; Jousset, A. Plant diversity improves protection against soil-borne pathogens by fostering antagonistic bacterial communities. J. Ecol. 2012, 100, 597-604. [CrossRef]

148. Haas, D.; Défago, G. Biological control of soil-borne pathogens by fluorescent pseudomonads. Nat. Rev. Microbiol. 2005, 3, 307-319. [CrossRef] [PubMed]

149. Matsumoto, H.; Fan, X.; Wang, Y.; Kusstatscher, P.; Duan, J.; Wu, S.; Chen, S.; Qiao, K.; Wang, Y.; Ma, B. Bacterial seed endophyte shapes disease resistance in rice. Nat. Plants 2021, 7, 60-72. [CrossRef] [PubMed]

150. Kwak, Y.-S.; Weller, D.M. Take-all of wheat and natural disease suppression: A review. Plant. Pathol. J. 2013, 29, 125. [CrossRef] [PubMed]

151. Bonanomi, G.; Antignani, V.; Capodilupo, M.; Scala, F. Identifying the characteristics of organic soil amendments that suppress soilborne plant diseases. Soil Biol. Biochem. 2010, 42, 136-144. [CrossRef]

152. Santhanam, R.; Weinhold, A.; Goldberg, J.; Oh, Y.; Baldwin, I.T. Native root-associated bacteria rescue a plant from a sudden-wilt disease that emerged during continuous cropping. Proc. Natl. Acad. Sci. USA 2015, 112, E5013-E5020. [CrossRef] [PubMed]

153. Hunziker, L.; Bönisch, D.; Groenhagen, U.; Bailly, A.; Schulz, S.; Weisskopf, L. Pseudomonas strains naturally associated with potato plants produce volatiles with high potential for inhibition of Phytophthora infestans. Appl. Environ. Microbiol. 2015, 81, 821-830. [CrossRef]

154. Peralta, A.L.; Sun, Y.; McDaniel, M.D.; Lennon, J.T. Crop rotational diversity increases disease suppressive capacity of soil microbiomes. Ecosphere 2018, 9, e02235. [CrossRef]

155. Ab Rahman, S.F.S.; Singh, E.; Pieterse, C.M.; Schenk, P.M. Emerging microbial biocontrol strategies for plant pathogens. Plant Sci. 2018, 267, 102-111. [CrossRef]

156. Finkel, O.M.; Castrillo, G.; Paredes, S.H.; González, I.S.; Dangl, J.L. Understanding and exploiting plant beneficial microbes. Curr. Opin. Plant. Biol. 2017, 38, 155-163. [CrossRef]

157. Castrillo, G.; Teixeira, P.J.P.L.; Paredes, S.H.; Law, T.F.; de Lorenzo, L.; Feltcher, M.E.; Finkel, O.M.; Breakfield, N.W.; Mieczkowski, P.; Jones, C.D. Root microbiota drive direct integration of phosphate stress and immunity. Nature 2017, 543, 513-518. [CrossRef] [PubMed]

158. Innerebner, G.; Knief, C.; Vorholt, J.A. Protection of Arabidopsis thaliana against leaf-pathogenic Pseudomonas syringae by Sphingomonas strains in a controlled model system. Appl. Environ. Microbiol. 2011, 77, 3202-3210. [CrossRef]

159. Vogel, C.; Bodenhausen, N.; Gruissem, W.; Vorholt, J.A. The Arabidopsis leaf transcriptome reveals distinct but also overlapping responses to colonization by phyllosphere commensals and pathogen infection with impact on plant health. New Phytol. 2016, 212, 192-207. [CrossRef]

160. Haney, C.H.; Samuel, B.S.; Bush, J.; Ausubel, F.M. Associations with rhizosphere bacteria can confer an adaptive advantage to plants. Nat. Plants 2015, 1, 15051. [CrossRef]

161. Chen, Y.; Wang, J.; Yang, N.; Wen, Z.; Sun, X.; Chai, Y.; Ma, Z. Wheat microbiome bacteria can reduce virulence of a plant pathogenic fungus by altering histone acetylation. Nat. Commun. 2018, 9, 3429. [CrossRef] [PubMed]

162. Sahu, K.P.; Kumar, A.; Patel, A.; Kumar, M.; Gopalakrishnan, S.; Prakash, G.; Rathour, R.; Gogoi, R. Rice blast lesions: An Unexplored phyllosphere microhabitat for novel antagonistic bacterial species against Magnaporthe oryzae. Microb. Ecol. 2020, 81, 731-745. [CrossRef]

163. Spence, C.; Alff, E.; Johnson, C.; Ramos, C.; Donofrio, N.; Sundaresan, V.; Bais, H. Natural rice rhizospheric microbes suppress rice blast infections. BMC Plant. Biol. 2014, 14, 1-17. [CrossRef] 
164. Kesten, C.; Gámez-Arjona, F.M.; Menna, A.; Scholl, S.; Dora, S.; Huerta, A.I.; Huang, H.Y.; Tintor, N.; Kinoshita, T.; Rep, M. Pathogen-induced $\mathrm{pH}$ changes regulate the growth-defense balance in plants. EMBO J. 2019, 38, e101822. [CrossRef]

165. Lazcano, C.; Boyd, E.; Holmes, G.; Hewavitharana, S.; Pasulka, A.; Ivors, K. The rhizosphere microbiome plays a role in the resistance to soil-borne pathogens and nutrient uptake of strawberry cultivars under field conditions. Sci. Rep. 2021, 11, 3188. [CrossRef] [PubMed]

166. Garbeva, P.; Postma, J.; Van Veen, J.; Van Elsas, J. Effect of above-ground plant species on soil microbial community structure and its impact on suppression of Rhizoctonia solani AG3. Environ. Microbiol. 2006, 8, 233-246. [CrossRef]

167. Vannier, N.; Agler, M.; Hacquard, S. Microbiota-mediated disease resistance in plants. PLoS Pathog. 2019, 15, e1007740. [CrossRef]

168. Ryu, C.-M.; Farag, M.A.; Hu, C.-H.; Reddy, M.S.; Kloepper, J.W.; Paré, P.W. Bacterial volatiles induce systemic resistance in Arabidopsis. Plant Physiol. 2004, 134, 1017-1026. [CrossRef]

169. Pršić, J.; Ongena, M. Elicitors of plant immunity triggered by beneficial bacteria. Front. Plant Sci. 2020, 11, 594530. [CrossRef]

170. Iavicoli, A.; Boutet, E.; Buchala, A.; Métraux, J.-P. Induced systemic resistance in Arabidopsis thaliana in response to root inoculation with Pseudomonas fluorescens CHA0. MPMI 2003, 16, 851-858. [CrossRef]

171. Ongena, M.; Jourdan, E.; Adam, A.; Paquot, M.; Brans, A.; Joris, B.; Arpigny, J.L.; Thonart, P. Surfactin and fengycin lipopeptides of Bacillus subtilis as elicitors of induced systemic resistance in plants. Environ. Microbiol. 2007, 9, 1084-1090. [CrossRef]

172. Stringlis, I.A.; Yu, K.; Feussner, K.; de Jonge, R.; van Bentum, S.; van Verk, M.C.; Berendsen, R.L.; Bakker, P.A.; Feussner, I.; Pieterse, C.M. MYB72-dependent coumarin exudation shapes root microbiome assembly to promote plant health. Proc. Natl. Acad. Sci. USA 2018, 115, E5213-E5222. [CrossRef]

173. Köhl, J.; Kolnaar, R.; Ravensberg, W.J. Mode of action of microbial biological control agents against plant diseases: Relevance beyond efficacy. Front. Plant Sci. 2019, 10, 845. [CrossRef] [PubMed]

174. Raaijmakers, J.M.; Paulitz, T.C.; Steinberg, C.; Alabouvette, C.; Moënne-Loccoz, Y. The rhizosphere: A playground and battlefield for soilborne pathogens and beneficial microorganisms. Plant Soil 2009, 321, 341-361. [CrossRef]

175. Pieterse, C.M.; van Pelt, J.A.; Verhagen, B.W.; Ton, J.; van Wees, S.C.; Léon-Kloosterziel, K.M.; Van Loon, L. Induced systemic resistance by plant growth-promoting rhizobacteria. Symbiosis 2003, 35, 39-54.

176. Mendes, R.; Kruijt, M.; de Bruijn, I.; Dekkers, E.; van der Voort, M.; Schneider, J.H.; Piceno, Y.M.; DeSantis, T.Z.; Andersen, G.L.; Bakker, P.A. Deciphering the rhizosphere microbiome for disease-suppressive bacteria. Science 2011, 332, 1097-1100. [CrossRef] [PubMed]

177. Wang, E.; Schornack, S.; Marsh, J.F.; Gobbato, E.; Schwessinger, B.; Eastmond, P.; Schultze, M.; Kamoun, S.; Oldroyd, G.E. A common signaling process that promotes mycorrhizal and oomycete colonization of plants. Curr. Biol. 2012, 22, $2242-2246$. [CrossRef]

178. Zamioudis, C.; Pieterse, C.M. Modulation of host immunity by beneficial microbes. MPMI 2012, 25, 139-150. [CrossRef]

179. Kloppholz, S.; Kuhn, H.; Requena, N. A secreted fungal effector of Glomus intraradices promotes symbiotic biotrophy. Curr. Biol. 2011, 21, 1204-1209. [CrossRef] [PubMed]

180. Plett, J.M.; Kemppainen, M.; Kale, S.D.; Kohler, A.; Legué, V.; Brun, A.; Tyler, B.M.; Pardo, A.G.; Martin, F. A secreted effector protein of Laccaria bicolor is required for symbiosis development. Curr. Biol. 2011, 21, 1197-1203. [CrossRef] [PubMed]

181. Brotman, Y.; Landau, U.; Cuadros-Inostroza, Á.; Takayuki, T.; Fernie, A.R.; Chet, I.; Viterbo, A.; Willmitzer, L. Trichoderma-plant root colonization: Escaping early plant defense responses and activation of the antioxidant machinery for saline stress tolerance. PLoS Pathog. 2013, 9, e1003221. [CrossRef]

182. Lakshmanan, V.; Castaneda, R.; Rudrappa, T.; Bais, H.P. Root transcriptome analysis of Arabidopsis thaliana exposed to beneficial Bacillus subtilis FB17 rhizobacteria revealed genes for bacterial recruitment and plant defense independent of malate efflux. Planta 2013, 238, 657-668. [CrossRef]

183. Millet, Y.A.; Danna, C.H.; Clay, N.K.; Songnuan, W.; Simon, M.D.; Werck-Reichhart, D.; Ausubel, F.M. Innate immune responses activated in Arabidopsis roots by microbe-associated molecular patterns. Plant. Cell 2010, 22, 973-990. [CrossRef] [PubMed]

184. Dubey, A.; Malla, M.A.; Khan, F.; Chowdhary, K.; Yadav, S.; Kumar, A.; Sharma, S.; Khare, P.K.; Khan, M.L. Soil microbiome: A key player for conservation of soil health under changing climate. Biodivers. Conserv. 2019, 28, 2405-2429. [CrossRef]

185. Bonanomi, G.; Lorito, M.; Vinale, F.; Woo, S.L. Organic amendments, beneficial microbes, and soil microbiota: Toward a unified framework for disease suppression. Annu. Rev. Phytopathol. 2018, 56, 1-20. [CrossRef]

186. Ling, N.; Zhu, C.; Xue, C.; Chen, H.; Duan, Y.; Peng, C.; Guo, S.; Shen, Q. Insight into how organic amendments can shape the soil microbiome in long-term field experiments as revealed by network analysis. Soil Biol. Biochem. 2016, 99, 137-149. [CrossRef]

187. Porter, S.S.; Bantay, R.; Friel, C.A.; Garoutte, A.; Gdanetz, K.; Ibarreta, K.; Moore, B.M.; Shetty, P.; Siler, E.; Friesen, M.L. Beneficial microbes ameliorate abiotic and biotic sources of stress on plants. Funct. Ecol. 2020, 34, 2075-2086. [CrossRef]

188. Stringlis, I.A.; de Jonge, R.; Pieterse, C.M. The age of coumarins in plant-microbe interactions. Plant Cell Physiol. 2019, 60, 1405-1419. [CrossRef]

189. Voges, M.J.; Bai, Y.; Schulze-Lefert, P.; Sattely, E.S. Plant-derived coumarins shape the composition of an Arabidopsis synthetic root microbiome. Proc. Natl. Acad. Sci. USA 2019, 116, 12558-12565. [CrossRef]

190. Cotton, T.A.; Pétriacq, P.; Cameron, D.D.; Al Meselmani, M.; Schwarzenbacher, R.; Rolfe, S.A.; Ton, J. Metabolic regulation of the maize rhizobiome by benzoxazinoids. ISME J. 2019, 13, 1647-1658. [CrossRef] 
191. Hart, M.M.; Antunes, P.M.; Chaudhary, V.B.; Abbott, L.K. Fungal inoculants in the field: Is the reward greater than the risk? Funct. Ecol. 2018, 32, 126-135. [CrossRef]

192. Kong, Z.; Hart, M.; Liu, H. Paving the way from the lab to the field: Using synthetic microbial consortia to produce high-quality crops. Front. Plant Sci. 2018, 9, 1467. [CrossRef] [PubMed]

193. Vyas, P.; Kumar, D.; Dubey, A.; Kumar, A. Screening and characterization of Achromobacter xylosoxidans isolated from rhizosphere of Jatropha curcas L. (energy crop) for plant-growth-promoting traits. J. Adv. Res. Biotech. 2018, 3, 1-8. [CrossRef]

194. Del Carmen Orozco-Mosqueda, M.; del Carmen Rocha-Granados, M.; Glick, B.R.; Santoyo, G. Microbiome engineering to improve biocontrol and plant growth-promoting mechanisms. Microbiol. Res. 2018, 208, 25-31. [CrossRef] [PubMed]

195. Molina-Romero, D.; Baez, A.; Quintero-Hernández, V.; Castañeda-Lucio, M.; Fuentes-Ramírez, L.E.; Bustillos-Cristales, M.d.R.; Rodríguez-Andrade, O.; Morales-García, Y.E.; Munive, A.; Muñoz-Rojas, J. Compatible bacterial mixture, tolerant to desiccation, improves maize plant growth. PLoS ONE 2017, 12, e0187913. [CrossRef] [PubMed]

196. Ma, Y.; Rajkumar, M.; Oliveira, R.S.; Zhang, C.; Freitas, H. Potential of plant beneficial bacteria and arbuscular mycorrhizal fungi in phytoremediation of metal-contaminated saline soils. J. Hazard. Mater. 2019, 379, 120813. [CrossRef] [PubMed]

197. Chihaoui, S.-A.; Trabelsi, D.; Jdey, A.; Mhadhbi, H.; Mhamdi, R. Inoculation of Phaseolus vulgaris with the nodule-endophyte Agrobacterium sp. 10C2 affects richness and structure of rhizosphere bacterial communities and enhances nodulation and growth. Arch. Microbiol. 2015, 197, 805-813. [CrossRef]

198. Jacoby, R.P.; Koprivova, A.; Kopriva, S. Pinpointing secondary metabolites that shape the composition and function of the plant microbiome. J. Exp. Bot. 2020, 72, 57-69. [CrossRef] [PubMed]

199. Rojas-Solís, D.; Zetter-Salmón, E.; Contreras-Pérez, M.; del Carmen Rocha-Granados, M.; Macías-Rodríguez, L.; Santoyo, G. Pseudomonas stutzeri E25 and Stenotrophomonas maltophilia CR71 endophytes produce antifungal volatile organic compounds and exhibit additive plant growth-promoting effects. Biocatal. Agric. Biotechnol. 2018, 13, 46-52. [CrossRef]

200. Tsolakidou, M.-D.; Stringlis, I.A.; Fanega-Sleziak, N.; Papageorgiou, S.; Tsalakou, A.; Pantelides, I.S. Rhizosphere-enriched microbes as a pool to design synthetic communities for reproducible beneficial outputs. FEMS Microbiol. Ecol. 2019, 95, fiz138. [CrossRef] [PubMed]

201. Jain, A.; Singh, S.; Kumar Sarma, B.; Bahadur Singh, H. Microbial consortium-mediated reprogramming of defence network in pea to enhance tolerance against Sclerotinia sclerotiorum. J. Appl. Microbiol. 2012, 112, 537-550. [CrossRef] [PubMed]

202. Marimuthu, S.; Ramamoorthy, V.; Samiyappan, R.; Subbian, P. Intercropping system with combined application of Azospirillum and Pseudomonas fluorescens reduces root rot incidence caused by Rhizoctonia bataticola and increases seed cotton yield. J. Phytopathol. 2013, 161, 405-411. [CrossRef]

203. George, C.; Kohler, J.; Rillig, M.C. Biochars reduce infection rates of the root-lesion nematode Pratylenchus penetrans and associated biomass loss in carrot. Soil Biol. Biochem. 2016, 95, 11-18. [CrossRef]

204. Johnston-Monje, D.; Raizada, M.N. Conservation and diversity of seed associated endophytes in Zea across boundaries of evolution, ethnography and ecology. PLoS ONE 2011, 6, e20396. [CrossRef] [PubMed]

205. Ke, J.; Wang, B.; Yoshikuni, Y. Microbiome engineering: Synthetic biology of plant-associated microbiomes in sustainable agriculture. Trends Biotechnol. 2020, 39, 244-261. [CrossRef]

206. Paungfoo-Lonhienne, C.; Rentsch, D.; Robatzek, S.; Webb, R.I.; Sagulenko, E.; Näsholm, T.; Schmidt, S.; Lonhienne, T.G. Turning the table: Plants consume microbes as a source of nutrients. PLoS ONE 2010, 5, e11915. [CrossRef]

207. Wintermans, P.C.; Bakker, P.A.; Pieterse, C.M. Natural genetic variation in Arabidopsis for responsiveness to plant growthpromoting rhizobacteria. Plant Mol. Biol. Rep. 2016, 90, 623-634. [CrossRef]

208. Chen, T.; Nomura, K.; Wang, X.; Sohrabi, R.; Xu, J.; Yao, L.; Paasch, B.C.; Ma, L.; Kremer, J.; Cheng, Y. A plant genetic network for preventing dysbiosis in the phyllosphere. Nature 2020, 580, 653-657. [CrossRef] [PubMed]

209. Horton, M.W.; Bodenhausen, N.; Beilsmith, K.; Meng, D.; Muegge, B.D.; Subramanian, S.; Vetter, M.M.; Vilhjálmsson, B.J.; Nordborg, M.; Gordon, J.I. Genome-wide association study of Arabidopsis thaliana leaf microbial community. Nat. Commun. 2014, 5, 5320. [CrossRef]

210. Chen, X.; Marszałkowska, M.; Reinhold-Hurek, B. Jasmonic acid, not salicyclic acid restricts endophytic root colonization of rice. Front. Plant Sci. 2020, 10, 1758. [CrossRef] [PubMed]

211. Mitter, B.; Pfaffenbichler, N.; Flavell, R.; Compant, S.; Antonielli, L.; Petric, A.; Berninger, T.; Naveed, M.; Sheibani-Tezerji, R.; von Maltzahn, G. A new approach to modify plant microbiomes and traits by introducing beneficial bacteria at flowering into progeny seeds. Front. Microbiol. 2017, 8, 11. [CrossRef]

212. Pérez-Jaramillo, J.E.; de Hollander, M.; Ramírez, C.A.; Mendes, R.; Raaijmakers, J.M.; Carrión, V.J. Deciphering rhizosphere microbiome assembly of wild and modern common bean (Phaseolus vulgaris) in native and agricultural soils from Colombia. Microbiome 2019, 7, 114. [CrossRef] [PubMed]

213. Balint-Kurti, P.; Simmons, S.J.; Blum, J.E.; Ballaré, C.L.; Stapleton, A.E. Maize leaf epiphytic bacteria diversity patterns are genetically correlated with resistance to fungal pathogen infection. MPMI 2010, 23, 473-484. [CrossRef]

214. Wagner, M.R.; Roberts, J.H.; Balint-Kurti, P.; Holland, J.B. Heterosis of leaf and rhizosphere microbiomes in field-grown maize. New Phytol. 2020, 228, 1055-1069. [CrossRef] [PubMed]

215. Pérez-Jaramillo, J.E.; Carrión, V.J.; de Hollander, M.; Raaijmakers, J.M. The wild side of plant microbiomes. Microbiome 2018, 6, 143. [CrossRef] [PubMed] 
216. Morella, N.M.; Weng, F.C.-H.; Joubert, P.M.; Metcalf, C.J.E.; Lindow, S.; Koskella, B. Successive passaging of a plant-associated microbiome reveals robust habitat and host genotype-dependent selection. Proc. Natl. Acad. Sci. USA 2020, 117, 1148-1159. [CrossRef]

217. Latz, M.A.; Kerrn, M.H.; Sørensen, H.; Collinge, D.B.; Jensen, B.; Brown, J.K.; Madsen, A.M.; Jørgensen, H.J.L. Succession of the fungal endophytic microbiome of wheat is dependent on tissue-specific interactions between host genotype and environment. Sci. Total Environ. 2021, 759, 143804. [CrossRef] [PubMed] 